AD

T.M. 38

\title{
Geomorphology and Sediments of the Chesapeake Bay Entrance
}

by

Edward P. Meisburger

TECHNICAL MEMORANDUM NO. 38

$$
\text { JUNE } 1972
$$
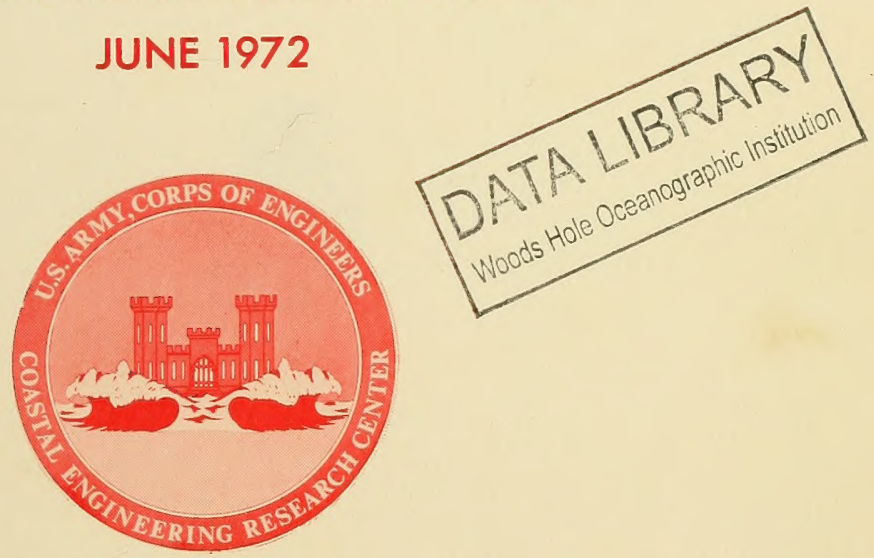

U. S. ARMY, CORPS OF ENGINEERS

COASTAL ENGINEERING

GB

450

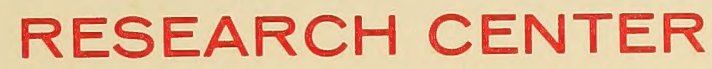

. $\mathrm{MH}_{4}$

no. 38

Approved for public release; distribution unlimited. 
Reprint or republication of any of this material sha11 give appropriate credit to the U.S. Army Coastal Engineering Research Center.

Limited free distribution within the United States of single copies of this publication is made by:

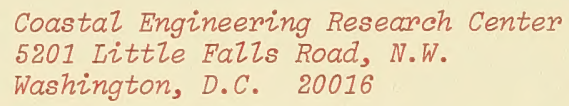

The findings in this report are not to be construed as an official Department of the Army position unless so designated by other authorized documents 


\section{Geomorphology and Sediments of the Chesapeake Bay Entrance}

by

Edward P. Meisburger

TECHNICAL MEMORANDUM NO. 38 JUNE 1972

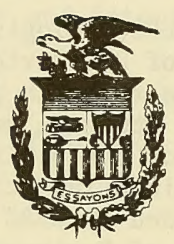

U. S. ARMY, CORPS OF ENGINEERS

COASTAL ENGINEERING RESEARCH CENTER

Approved for public release; distribution unlimited. 
The entrance of the Chesapeake Bay and the Atlantic Ocean in the vicinity of Cape Charles and Cape Henry were surveyed to study the bottom morphology and sediments, and subbottom structure, in an effort to locate suitable sand deposits in volumes great enough to economically restore and periodically nourish the shore. Seismic reflection profiles and sediment cores were the basis for the study. Field and laboratory techniques used for the profiles and sediment obtained from the sea floor in lower bay and ocean are presented. Most of the study area is less than 35 feet deep; distribution of shallow bay and inshore terraces and deeper water are shown in the figures. The study included analyses of borings taken along the route of the Chesapeake Bay Bridge Tunne1 by the Bridge Commission in 1960 and 1961. Cores obtained for a dredging study by the Norfolk District, Corps of Engineers, 1970, were made available and were used in the study.

\section{FOREWORD}

This report is one of a series which will describe results of the CERC Inner Continental Shelf Sediment and Structure (ICONS) Study, previously referred to as the Sand Inventory Program.

Edward P. Meisburger, a CERC geologist, prepared the report under the direction and supervision of Dr. David B. Duane, Chief of the Geology Branch. As part of the research program of the Engineering Development Division the ICONS Study is under the general supervision of Mr. George M. Watts, Chief of the Division. The field work for the study was done by National Engineering Science Company (NESCO) under contract (DACW 65-68-0001) funded by CERC but awarded and administered by the Norfolk District, Corps of Engineers.

Cores taken during the field program are stored at the Smithsonian Institution Oceanographic Sorting Center (SOSC), Washington, D. C. 20390. Microfilm of the seismic profiles, the 1:80,000 navigational plots, and other ancillary data are stored at the National Oceanographic Data Center (NODC), Rockville, Maryland 20852. Requests for information relative to these items should be directed to SOSC or NODC.

At the time of publication Lieutenant Colone1 Don S. McCoy was Director of CERC; Thorndike Saville, Jr. was Technical Director.

NOTE: Comments on this publication are invited. Discussion will be published in the next issue of the CERC Bulletin.

This report is published under authority of Public Law 166, 79th Congress, approved July 31, 1945, as supplemented by Public Law 172, 88th Congress, approved November 7, 1963. 
Section I. INTRODUCTION ................ 1

1. Background .............. . . 1

2. Field and Laboratory Procedures. . . . . . 2

3. Scope................ 4

Section II. HYDROGRAPHY AND GEOLOGY OF THE STUDY AREA. . . . 8

1. Hydrography. . . . . . . . . . . . . 8

2. Geologic Setting . . . . . . . . . 10

3. Shallow Subbottom Structure and Bedding. . . 15

4. Sediment Characteristics and Distribution. . . 20

Section III. DISCUSSION . . . . . . . . . 32

Section IV. SAND RESOURCES . . . . . . . . . . . . 37

1. Sand Volume Requirements . . . . . . . 37

2. Sand Suitability and Potential Borrow Areas. . 37

Section V. SUMMARY. ................ 41

APPENDIX A - SELECTED GEOPHYSICAL PROFILES. . . . . . . . . 42

APPENDIX B - GRANULOMETRIC DATA . . . . . . . . . 45

APPENDIX C - SEDIMENT DESCRIPTIONS. . . . . . . . . 48

LITERATURE CITED. . . . . . . . . . . . . . 59

Figure

1. Map of the Chesapeake Bight region showing coverage of the Chesapeake Bay Entrance ICONS survey. . . . . . . .

2a. Geophysical track lines and core locations for the Chesapeake Bay Entrance survey grid .........

2b. Geophysical track lines and core locations for the Virginia Beach reconnaissance survey..........

3. Gross morphology of the bottom in Chesapeake Bay Entrance area. . . . . . . . . . . . . . . 
4. Geological cross section of Chesapeake Bay Entrance along the Bridge Tunnel route compiled from engineering borings.

5. Contours on a reflector within the presumed Miocene section underlying the study area............ 16

6. Contours on the buried erosion surface underlying the study area................

7. Surface sediment distribution in the study area based on gross characteristics............. 21

8. Typical fine gray sand (Unit A) from Chesapeake Bay Entrance ..................

9. Size distribution for typical samples from the fine gray sand (Unit A).............. 23

10. Typical samples of the coarse gravelly sand (Unit E) occurring in Thimble Shoals Channel and under Tail of the Horseshoe. . . . . . . . . . . . . 24

11. Size distribution for typical samples of Unit E sand . . 25

12. Photos of typical samples from the coarse, brown, shelly . 27

13. Size distribution curves for typical samples of the coarse, brown, shelly sand occurring in patches on the Cape Charles Terrace..............

14. Histogram of the phi mean diameter of 95 samples from cores in the fine gray sand (Unit) ..........

15. Isopachous map of sediment thickness over the "blue" reflector surface. . . . . . . . . . . . .

16. Detailed plan view of the Thimble Shoals outcrop of Type E sand. Crosshatched area outlines the area of outcrop where the most economically recoverable material lies. Contours are on the first subbottom reflector... 


\section{GEOMORPHOLOGY AND SEDIMENTS \\ OF THE \\ CHESAPEAKE BAY ENTRANCE}

by

Edward P. Meisburger

Section I. INTRODUCTION

\section{Background}

Ocean beaches and dunes constitute a vital buffer zone between the sea and coastal areas and provide at the same time much needed recreation areas for the public. The construction, improvement, and maintenance of beaches through the artificial placement (nourishment) of sand on the shore is one of several protection methods. This technique has gained prominence in coastal engineering largely as a result of the successful program initiated at Santa Barbara, California, in 1938 (Hall, 1952).

Where the specified plan of improvement involves shore restoration and periodic nourishment, large volumes of sand fill may be involved. In recent years it has become increasingly difficult to obtain suitable sand from lagoons or inland sources in sufficient quantities and at an economical cost for beach fill purposes. This is due to increased land value, diminution and depletion of previously used nearby sources, and added cost of transporting sand from areas increasingly remote. Material composing the bottom and subbottom of estuaries, lagoons, and bays, is often too fine-grained and not suitable for long-term protection. While the loss of some fines is inevitable as the new beach sediment seeks equilibrium with its environment, it is possible to estimate the stability of the beach fill, and keep the loss to a minimum through selection of the most suitable fill material (Krumbein and James, 1965).

The problem of locating a suitable and economical sand supply led the Corps of Engineers to a search for new unexploited deposits of sand. The search focused offshore with the intent to explore and inventory deposits suitable for future beach fill requirements, and subsequently to develop and refine techniques for transferring offshore sand to the beach. The exploration program is conducted through the U. S. Army Coastal Engineering Research Center (CERC). An initial phase in developing techniques for transferring offshore sand to the beach is described by Mauriello (1967).

Formerly called the sand inventory program, it was begun in 1964 with a survey off the New Jersey Coast. Subsequent surveys included the inshore waters off New England, New York, Florida, Maryland, and parts of Delaware and Virginia. Recognizing the broader application of 
the information collected in the conduct of the research program toward the CERC mission, especially in terms of Continental Shelf structure (Meisburger and Duane, 1969), Continental Shelf Sedimentation (Field, Meisburger and Duane, 1971), and its potential application to historical geology and engineering studies of the shelf, the sand inventory program is now referred to as the Inner Continental Shelf Sediment and Structure Program (ICONS).

\section{Field and Laboratory Procedures}

The exploration phase of the ICONS program uses seismic reflection profiling supplemented by cores of the marine bottom. Additional supporting data for the studies are obtained from USCEGS hydrographic boat sheets and related published literature. Planning, and seismic-reflection profiling, coring, positioning, and analysis of sediment obtained in the cores are detailed in Geomorphology and Sediment Characteristics of the Nearshore Continental Shelf, Miami to Palm Beach; Florida (Duane and Meisburger, 1969). However, a brief description of techniques is germane to this paper and follows.

a. Planning - Survey tracklines were laid out by the CERC Geology Branch staff in either of two line patterns: grid and reconnaissance lines. A grid pattern (line spacing about 1 statute mile) was used to cover areas where a more detailed development of bottom and subbottom conditions was desired. Reconnaissance lines are one or several continuous zigzag lines followed to explore areas between grids, and to provide a means of correlating sonic reflection horizons between grids. Reconnaissance lines provide sufficient information to show the general morphologic and geologic aspect of the area covered, and to identify the best places for additional data collection.

Selection of core sites was based on a continuing review of the seismic profiles as they became available during the survey. This procedure allowed core-site selection based on the best information available; it also permitted the contractor to complete coring in one area before moving his base to the next area.

b. Seismic Reflection Profiling is a technique in wide use for delineating subbottom structures and bedding planes in sea floor sediments and rocks. Continuous reflections are obtained by generating repetitive high-energy, sound pulses near the water surface and recording "echoes" reflected from the bottom-water interface, and subbottom interfaces between acoustically dissimilar materials. In general, the compositional and physical properties which commonly differentiate sediments and rocks also produce acoustic contrasts. Thus, an acoustic profile is roughly comparable to a geologic cross section.

Seismic-reflection surveys of marine areas are made by towing sound-generating sources and receiving instruments behind a survey vesse 1 which follows predetermined survey tracklines. For continuous 
profiling, the sound source is fired at a rapid rate, and returning signals from bottom and subbottom interfaces are received by one or more hydrophones. Returning signals are amplified and fed to a recorder which graphically plots the two-way signal travel time. Assuming a constant velocity for sound in water and shelf sediments, a vertical depth scale can be constructed to the chart paper. Horizontal location is obtained by frequent navigational fixes keyed to the chart record by an event marker, and by interpolation between fixes.

A more detailed discussion of seismic profiling techniques can be found in a number of technical publications (Miller et al., 1967; Ewing, 1963; Hersey, 1963; and Moore and Palmer, 1968).

Geophysical work for the preșent study was accomplished with a seismic system using compressed air as a sound energy source. Two "air guns" were used simultaneously during the survey. A low energy, high resolution gun source with a 1-cubic-inch chamber was used to produce a signal which provides good resolution but limited penetration. Returns from this source were recorded directly on 8-inch-wide electronsensitive paper using a recorder sweep speed of $125 \mathrm{milliseconds.} \mathrm{The} \mathrm{second} \mathrm{gun}$ had a 3-cubic-inch chamber, and its returns were recorded on magnetic tape and later played back through a recorder for display on 19-inchwide recorder paper. The latter source provides greater penetration, but resolution is reduced because of its longer pulse time.

c. Coring Techniques - A pneumatic vibrating hammer-driven coring assembly was used for obtaining cores from the survey area. The apparatus consists of a standard core barrel, liner, shoe and core catcher with the driver element fastened to the upper end of the barrel. These are enclosed in a self-supporting frame which allows the assembly to rest on the bottom during coring, thus permitting limited motion of the support vesse1 in response to waves. Power is supplied to the vibrator from a deck-mounted air compressor by means of a flexible hoseline. After the core is driven and returned, the liner containing the cored material is removed and capped.

d. Processing - Seismic records are analyzed to establish the principal bedding or structural features in upper subbottom strata. After preliminary analysis, record data is reduced to detailed crosssection profiles showing all reflective interfaces within the subbottom. Selected reflectors are then mapped to provide areal continuity of reflective horizons considered significant because of their extent and relationship to the general structure and geology of the study area. If possible, the upper mapped reflector is correlated with core data to provide a measure of continuity between cores.

Cores are visua11y inspected and logged aboard ship. After delivery to CERC, these cores are sampled by drilling through the liners and removing samples of representative material. After preliminary analysis, a number of representative cores are split to determine 
details of the bedding. Cores are set up for splitting on a wooden trough. A circular power saw mounted on a base which is designed to ride along the top of the trough is set to cut just through the liner. By making a cut in one direction and then reversing the saw base and making a second cut in the opposite direction, a 120-degree segment of the liner is cut. The sediment above the cut line is then removed with a spatula, and the core is logged, sampled and photographed.

Samples from cores are examined under a binocular microscope, and described in terms of gross lithology, mineralogy, and the type and abundance of skeletal fragments of organisms.

\section{Scope}

Continuous marine seismic reflection profiles and sediment cores were obtained by the contractor for an area of sea floor lying in lower Chesapeake Bay and the Atlantic Ocean in the general vicinity of Cape Charles and Cape Henry (Fig. 1). The exploration program consisted of a detailed survey covering 180 square miles in the Chesapeake Bay Entrance area adjacent to the Capes and a reconnaissance survey of the nearshore continental shelf off the southern Virginia Coast between Cape Henry and False Cape. Only that portion of the survey covering the Chesapeake Bay Entrance is reported in detail. (A report on the reconnaissance area will be made in the future when sufficient additional data is available for adequate analysis.)

During field operations, 290 statute miles of shallow and medium penetration seismic reflection survey of the bottom and subbottom underlying the report area were obtained (Figs. 2a. and 2b.). A total of sixty-one 4-inch diameter sediment cores up to 20 feet long were taken in the survey area by a pneumatic vibrator-hammer type coring apparatus. Additional data was obtained in 1970 from similar cores collected by the Norfolk District of the Corps of Engineers for a dredging survey. 


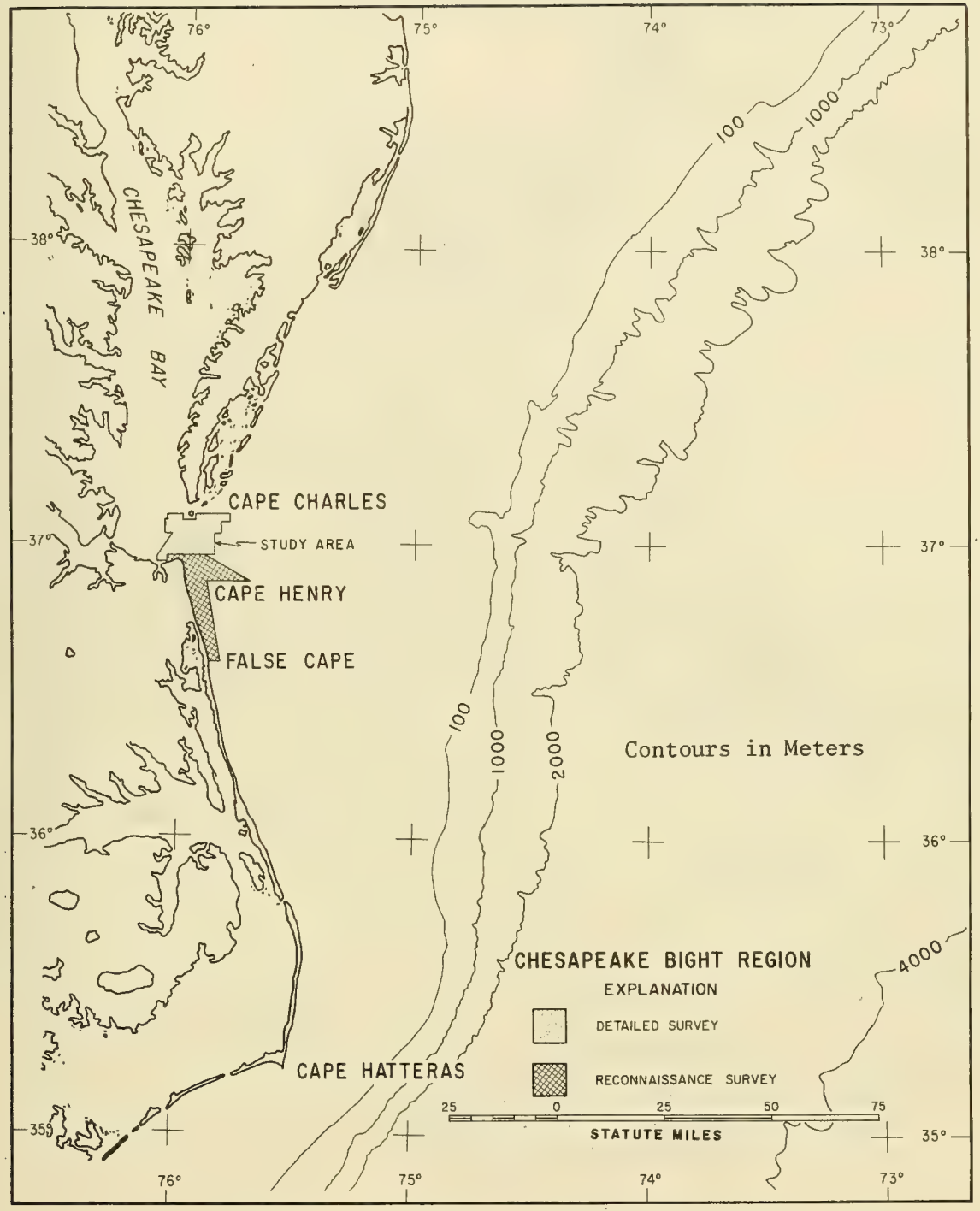

Figure 1. Map of the Chesapeake Bight region showing coverage of the Chesapeake Bay Entrance ICONS survey. 


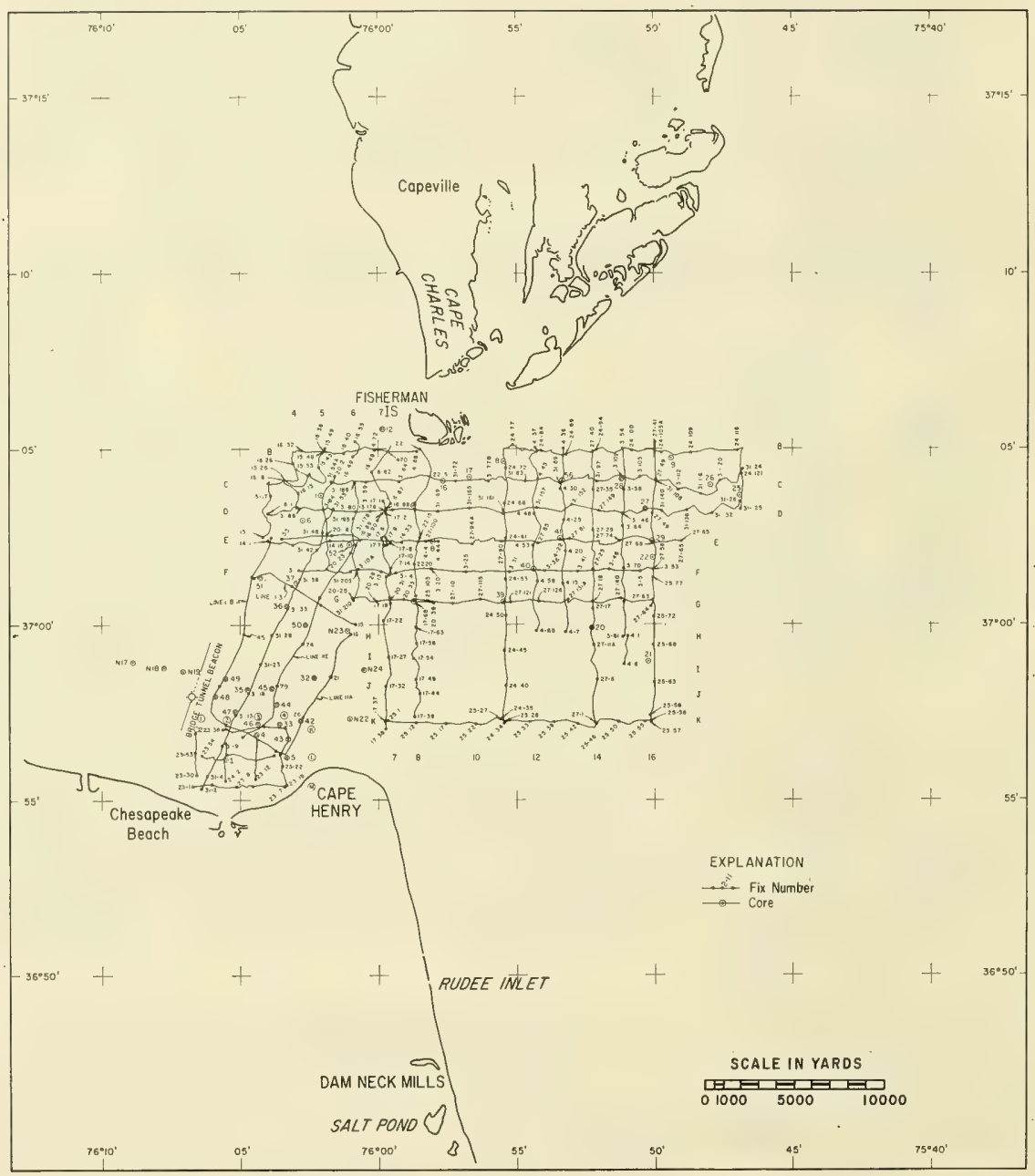

Figure 2a. Geophysical track lines and core locations for the Chesapeake Bay Entrance survey grid. 


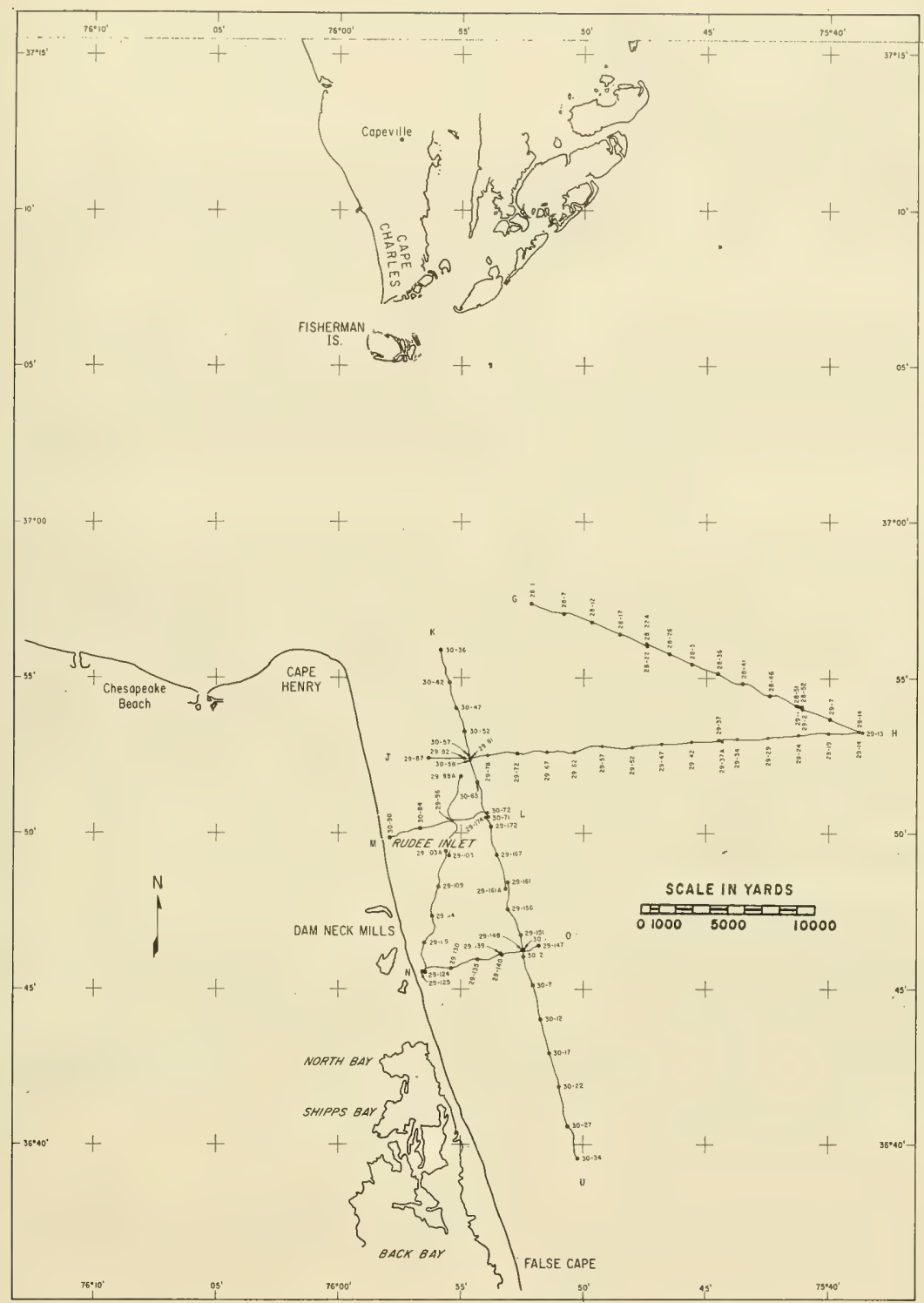

Figure 2b. Geophysical track lines and core locations for the Virginia Beach reconnaissance survey. 
Section II. HYDROGRAPHY AND GEOLOGY OF THE STUDY AREA

\section{Hydrography}

The Chesapeake Bay Entrance study area encompasses shallow portions of lower Chesapeake Bay and adjacent inshore sand flats in and around the bay entrance (Fig. 1). Most of this area lies under less than 35 feet of water. Deeper waters occur in the channels and closed depression in the lower Bay, and on the shelf seaward of the inshore flats and shoals.

Figure 3 shows the gross morphology of the bottom, (distribution of shallow bay and inshore terraces and deeper waters). The division between the main flats and deeper waters (which generally falls at around -30 to -36 feet MLW) is drawn at the top of the slope. Locally the slope is so gentle that the break is indefinite; here the dividing line was arbitrarily drawn at -33 feet MLW.

Although open water extends across Chesapeake Bay from Fisherman Island off Cape Charles to Cape Henry 10 nautical miles southward, the main inlet channel is less than 2 nautical miles wide. This channel is roughly in the form of a curved rectilinear depression with maximum depths of around 90 feet at MLW, and it is partially closed at both ends where the depth decreases to about 45 feet. Maximum depths in this channel occur NNE of Cape Henry. From this point the channel curves southeastward (and ends) about 5 nautical miles southeast of the Cape. West of Cape Henry, the main inlet channel terminates off Lynnhaven where it subdivides into three smaller and shallower channels: Thimble Shoals Channel leading westward to Hampton and Norfolk; Chesapeake Channel leading northward into middle and upper Chesapeake Bay; and a smal1 channe1 leading a short distance WSW into Lynnhaven Roads.

Cape Henry is steep-to and closely borders the deep water in the main inlet channel. Southward from Cape Henry the Virginia shore is bordered by a terrace-like flat at about -25 to -30 feet MLW. West of Cape Henry within the study limits the south Bay shore is fronted by a gently sloping bottom of sand, silt and sandy silt, extending north to Thimble Shoals Channel. A sandy flat called Tail of the Horseshoe lies between Thimble Shoals Channel and Chesapeake Channel. This flat-topped shoal is triangular with the apex at the confluence of the two flanking channels with the main inlet channel.

The most extensive sand terrace of the study area borders Cape Charles. On the Bay side this terrace extend's west and south as far as Chesapeake Channel; on the ocean side, inshore flats extend up to 6 nautical miles seaward and are prolonged further over the shelf by linear northeast-trending "finger" shoals.

South of Cape Charles the bay and ocean flats extend to within 2 miles of Cape Henry. Here a lobe of the flats projects along the flank southeast for about 7 nautical miles. 


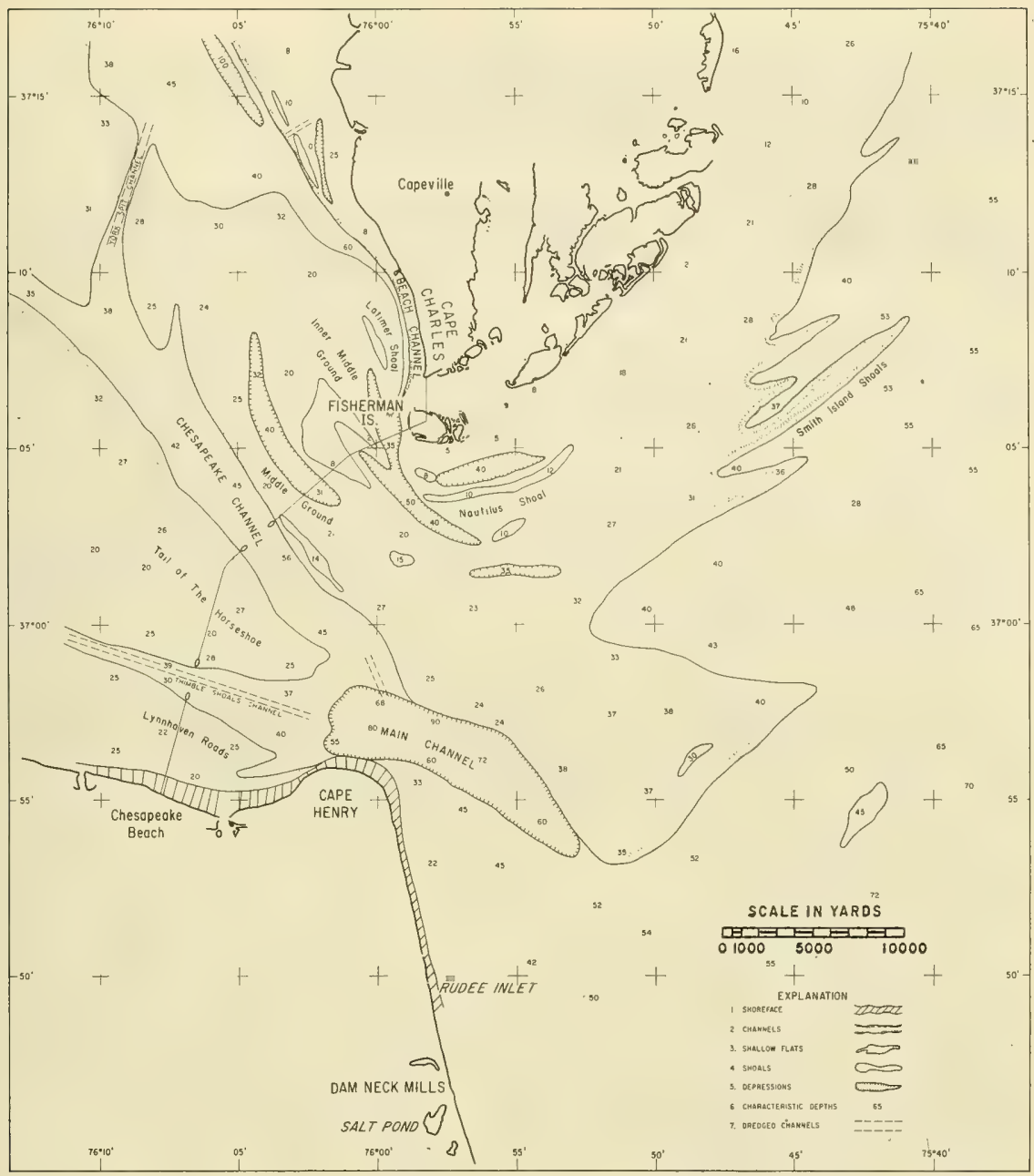

Figure 3. Gross morphology of the bottom in Chesapeake Bay Entrance area. Soundings are in feet. 
The Cape Charles terrace is characterized by numerous secondary morphological features, among which linear shoals and semi-closed depressions are most common. These linear features have been related to the tidal current pattern by Ludwick (1970).

Tides in Chesapeake Bay Entrance are semidiurnal with a mean range of around 3 feet and spring range of 3.5 feet. On the outer coast of Virginia, adjacent to the Bay Entrance, mean and spring ranges are about 3 and 4 feet respectively (U. S. Dept. of Commerce, 1971).

Tidal currents in the Bay Entrance vary in velocity from place to place, but are generally between 1 and 2 knots maximum on both flood and ebb flow as measured at the surface. (U. S. Dept. of Commerce 1967, Haight, Fennegan and Anderson 1930, Haight 1942, Ludwick 1970.)

Nontidal circulation in Chesapeake Bight (Cape Henlopen, Delaware to Cape Hatteras) has been reported by Harrison et al (1967) from drifter studies. Their study shows that bottom drifters set out on the shelf at less than $40 \mathrm{n}$. miles offshore tend to drift shoreward and that there is a pronounced tendency for seabed drifters to travel toward and even enter Chesapeake Bay.

Waves on the open coast south of Cape Henry as measured by the CERC wave gage at Virginia Beach are less than 3 feet high more than 90 percent of the time. Most of the Bay Entrance is open to easterly waves from offshore and to waves generated within the lower Bay which may reach heights of over 4 feet especially with northerly winds.

\section{Geologic Setting}

\section{a. Regional Aspects}

The Chesapeake Bay study area lies within the Atlantic Coastal plain Province. Basement rock underlies the area at depths greater than 2,000 feet (Ewing, et a1, 1937, Cederstrom 1945, Richards 1967). The basement is overlain by a succession of sediments and sedimentary rocks of the Potomac group (Cretaceous); Pamunky group (Eocene), Chesapeake group (Miocene) and a variety of Pleistocene age deposits collectively called the Columbia group (Cederstrom 1945) (Table 1). Recent deposits consisting largely of marine, estuarine and littoral sand, silt and clay are confined to submerged and coastal portion of the report area.

Miocene beds - the oldest of those with direct pertinence to this study - exceed 600 feet in thickness regionally and consist of layers of sand, grave1, diatomite and shel1s (Cederstrom 1945, Sinnott and Tibbitts 1954, 1957; Harrison et a1, 1965; Richards 1967). The Miocene section in southeastern Virginia is divided into four formations: the 
TABLE 1

Miocene and Post Miocene

Stratigraphic Column

Southeastern Virginia

AGE AND GROUP FORMATION

ELEVATION TO TOP (FEET)

\section{LITHOLOGIC CHARACTER}

\begin{tabular}{|c|c|c|c|}
\hline \multirow[t]{2}{*}{ Holocene } & \multicolumn{2}{|l|}{$\begin{array}{l}\text { Undifferen- } \\
\text { tiated }\end{array}$} & $\begin{array}{l}\text { Dune and beach, sand, } \\
\text { alluvium, lagoon silt } \\
\text { and clay }\end{array}$ \\
\hline & Dismal Swamp & \pm 5 & $\begin{array}{l}\text { Fresh water peat, clay } \\
\text { and sand }\end{array}$ \\
\hline \multirow{5}{*}{$\begin{array}{l}\text { P1eistocene } \\
\text { (Columbia } \\
\text { Group) }\end{array}$} & Sandbridge & -25 & Sand, clay and silt \\
\hline & Londonbridge & -17 & $\begin{array}{l}\text { Lagoonal silt and clay, } \\
\text { beach sand and gravel }\end{array}$ \\
\hline & Kempsville & -2 & $\begin{array}{l}\text { Beach sand, grave1 and } \\
\text { shel1, lagoonal peaty } \\
\text { clay }\end{array}$ \\
\hline & Norfolk & -35 & $\begin{array}{l}\text { Beach sand and gravel, } \\
\text { lagoonal fluvial and } \\
\text { estuarine clay and sand }\end{array}$ \\
\hline & Great Bridge & -45 & $\begin{array}{l}\text { Sand gravel, peat, clay } \\
\text { and silt }\end{array}$ \\
\hline \multirow{2}{*}{$\begin{array}{l}\text { Pliocene or } \\
\text { early } \\
\text { Pleistocene }\end{array}$} & Elberon & \pm 45 & $\begin{array}{l}\text { Lagoonal clay and silt } \\
\text { littoral sand }\end{array}$ \\
\hline & Bacons Castle & +30 & $\begin{array}{l}\text { Fluvial and flood plain } \\
\text { fine silt, gravel, clay, } \\
\text { fine sand }\end{array}$ \\
\hline P1iocene & Sedley & -5 & $\begin{array}{l}\text { Marine clay, silt and } \\
\text { fine sand }\end{array}$ \\
\hline $\begin{array}{l}\text { Miocene } \\
\text { (Chesapeake } \\
\text { Group) }\end{array}$ & $\begin{array}{l}\text { Yorktown } \\
\text { St. Marys } \\
\text { Choptank } \\
\text { Calvert }\end{array}$ & $\begin{array}{l}-30 \text { to }-160 \\
\text { insufficient } \\
\text { data }\end{array}$ & $\begin{array}{l}\text { Marine clay, silt, sand } \\
\text { shells }\end{array}$ \\
\hline
\end{tabular}


basal Calvert and, in ascending order, the Choptank, St. Marys and Yorktown. These formations do not crop out in or near the Bay Entrance area, and consequently are known only from wells and engineering soil borings. Because of apparent lithologic variability within formational boundaries and the sparse data available from wells, lithologic criteria for identifying these Miocene formations from well samples are not well established. Difficulties also exist in clearly defining paleontologic criteria (Sinnott and Tibbitts 1957, Harrison and others, 1965, McLean, 1966); consequently the Chesapeake group formations are largely undifferentiated in well logs.

In the eastern shore counties of Virginia (southern end of Delmarva Peninsula) the Miocene and post-Miocene contact has been shown by Sinnott and Tibbitts (1955 \& 1957) to lie generally less than 100 feet below sea leve1. Across the Bay Entrance, on the southeast Virginia coastal plain Miocene sediments have generally been thought to lie no deeper than 100 feet below sea level (Cederstrom 1945, Oaks \& Coch 1963, Oaks 1964). Rogers and Spencer (1968), however, believe:that Pleistocene deposits extend to 200 feet below sea level under the coastal plain directly south of the study area.

Pleistocene sediments of the Virginia coastal plain are collectively called the Columbia group. Subdivision of the group has until recently been based largely on topographic expression of the deposits which occur in a series of step-like terraces. Columbia group sediments are rarely differentiated in well samples because 1 ithological and paleontological criteria are not defined.

Recently Oaks and Coch (1963) re-defined the morphologic and stratigraphic units of the Pleistocene Columbia group and pre-Columbia post-Yorktown section of the southeastern coastal plain of Virginia (see also Oaks 1964 and Coch 1965 for detailed studies and revisions).

Pleistocene units recognized by Oaks (1964) east of Suffolk Scarp and pertinent to this study are in ascending order: Great Bridge, Norfolk, Kempsville, Londonbridge and Sandbridge formations. A11 but the Sandbridge formation appear to have been deposited at relative sea levels higher than the present level.

\section{b. Bay Entrance Study Area}

Strata underlying Chesapeake Bay Entrance are known primarily from a series of exploratory borings along the route of the Chesapeake Bay Bridge Tunnel crossing from Cape Charles to Chesapeake Beach. Logs of these borings (Chesapeake Bay Bridge and Tunnel Commission 1960-1961) and studies of the boring samples and data by Harrison (1963), Harrison et al (1965) and McLean (1966) have established the characteristics and probable age of sedimentary units underlying the Bridge Tunnel. 
A generalized profile of the Bridge-Tunnel route compiled from the borings and published studies is included in Figure 4. Sedimentary units have been generalized on the basis of gross lithology and age. The letters used to identify sedimentary units on Figure 4 and in the text are the same used on the Bridge Tunnel boring logs to identify these major sediment types. Subscripted numerals used on the logs to identify interunit variations of lithology and soil properties have not been used here.

Although the Bridge-Tunnel borings show a complex and diverse stratigraphy in detail, three main sedimentary bodies can be recognized. These bodies are continuous and lie in a vertical sequence. The lowermost body consists of greenish gray compact sand and sandy clay usually containing some silt and shells. The clay (Unit F) is generally uppermost, but also appears below and interbedded with the sand (Unit G). Standard blow counts (i.e., number of 140 pound hammer drops of 30 inches needed to drive a 2-inch outside diameter, split-spoon sampler 1-foot) are generally higher in the F-G units than in overlying bodies and usually range from 10 to 25 in the clayey unit (F) and 30 to 100 in the sandy unit (G). Studies by Harrison (1963), Harrison et al (1965). and McLean (1966) show that the F-G sediments are of Miocene age.

The surface of the F-G sediment body has been deeply eroded, presumably by fluvial processes during a lower relative stand of the sea (Figure 6). Deposited over the old erosion surface is a soft gray silty clay to sandy silt (Units B\&C). The lower part of the soft gray sediment is usually silty clay (Unit C) and the upper part a sandy silt (Unit B). In contrast to the underlying sediment, this material is characterized by its low bearing strength - standard blow counts rarely exceeded 5 blows per foot anywhere in the unit.

Units $\mathrm{B}$ and $\mathrm{C}$ occur along almost all of the Bridge-Tunnel route. At the south end (off Chesapeake Beach) the B-C sediment unit is replaced by a sand possibly similar to but probably not directly related to the A Unit described below. At the north end of the Bridge-Tunnel route the stratigraphic position of the B-C units is occupied by a complex set of localized lenses of sand, silt, and clay. The B-C sediment pinches out over highs in the underlying greenish-gray sediments and has possibly been eroded by recutting in the deep Channel $A$ under Fisherman Island. Dates on samples within the underlying B-C unit show that these sediments were deposited in shallow marine and fresh water environments during the Holocene transgression. (Harrison et al 1965, Maynard Nichols personal communication and faunal studies of McLean 1966, Ne1son 1969)

Fine wel1-sorted gray sand of very uniform appearance (Unit A) overlies the entire sequence between Fisherman Island and Thimble Shoals Channel. This is the characteristic surface sediment of the Bay Entrance area, and it occurs in the majority of cores obtained for this study. At the Bridge-Tunnel the sand is quite variable in shear 


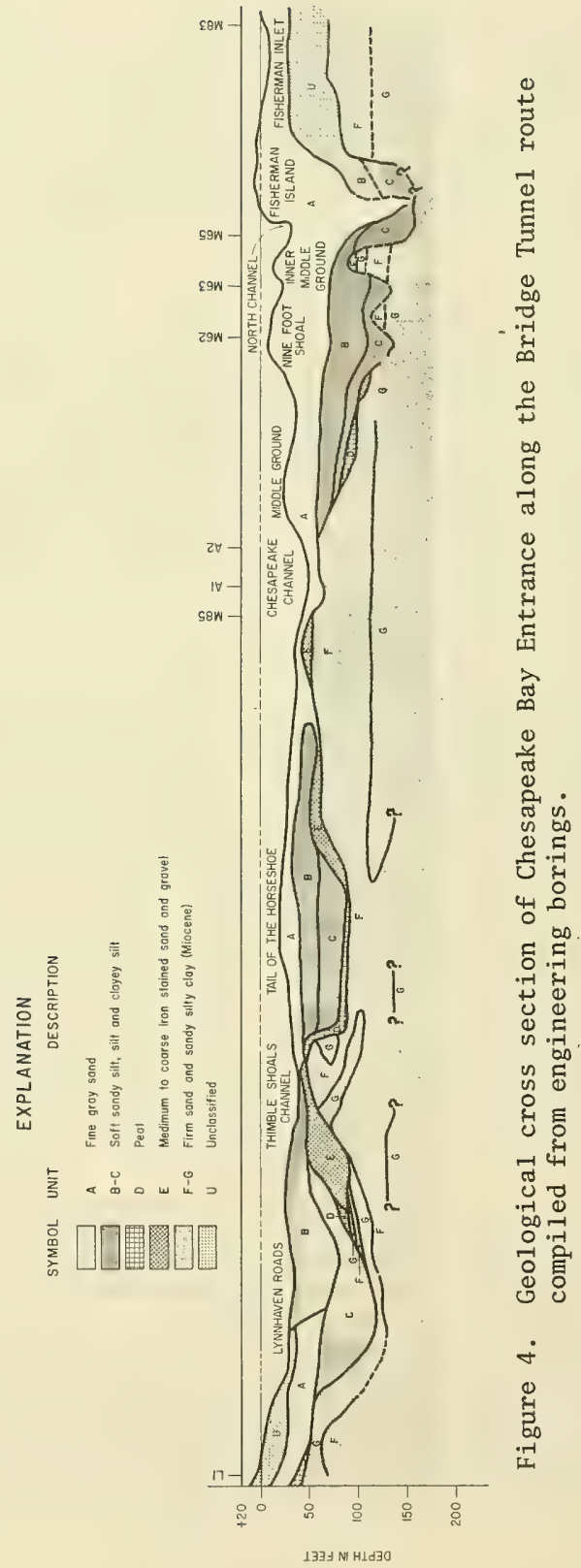


strength as indicated by a wide range of blow counts both from boring to boring and in places within the same bore hole. In general, however, standard blow counts average 10 to 20 in this unit.

Two, more restricted, units occur in the Bridge-Tunnel section. Both appear between the greenish-gray sediment (F\&G) and the overlying soft, gray sediments. One of these is a peat (Unit D); the other is a coarse, iron-stained sand (Unit E). Except for isolated patches, these units are concentrated in the area south of Chesapeake Channe1. There is no clear evidence that one overlies the other at any point; both apparently occupy the same stratigraphic horizon. However, for reasons discussed later, they are not believed to be time equivalents.

\section{Shallow Subbottom Structure and Bedding}

Two distinct patterns of bedding are evident in the 300 -foot section of subbottom strata covered by CERC seismic reflection records. In the lower part of the records, the reflector surfaces tend to be continuous, smooth, parallel to sub-parallel and dip very gently in a predominant east to southeast direction. Strata overlying this more or less uniformly bedded section tend to be discontinuous. Truncations and fadeout of reflector surfaces, secondary bedding between primary reflectors, and erosional features commonly occur in this section throughout the study area.

A buried erosion surface continuously underlies the entire study area. This surface is characterized by a number of deep channels, probably of fluvial origin, crossing the Bay Entrance area in a northwest to southeast direction, and a large channel trending east-west along the southern margin of the area. In places, the erosion surface divides the distinctively bedded upper and lower subbottom sections; elsewhere it lies within the upper sections.

The impression of complexity afforded by acoustic reflections in the upper section is verified in the western part of the study area by borings for the Chesapeake Bay Bridge Tunnel. These borings show frequent discontinuity in the lithologic and physical properties of sediments at similar depths, albeit gross lithology is more regular (Chesapeake Bay Bridge Tunnel Commission (1960-61), also see Harrison (1963), McLean (1966). In general, the complexly bedded section shown in records at and near the Bridge-Tunnel correlates with sediment units $A, B, C, D$, and $E$ of the Bridge-Tunnel borings (Figure 4), while the lower evenly bedded section correlates with the F and G units. These latter units have been identified as Miocene age sediments by Harrison (1963), Harrison et al (1965), and McLean (1966).

The general structural trend of strata contained in the evenly bedded lower section of the records is illustrated by the map in Figure 5 . This map shows contours on a prominent reflecting surface within the lower section. Other reflectors within the evenly bedded section 


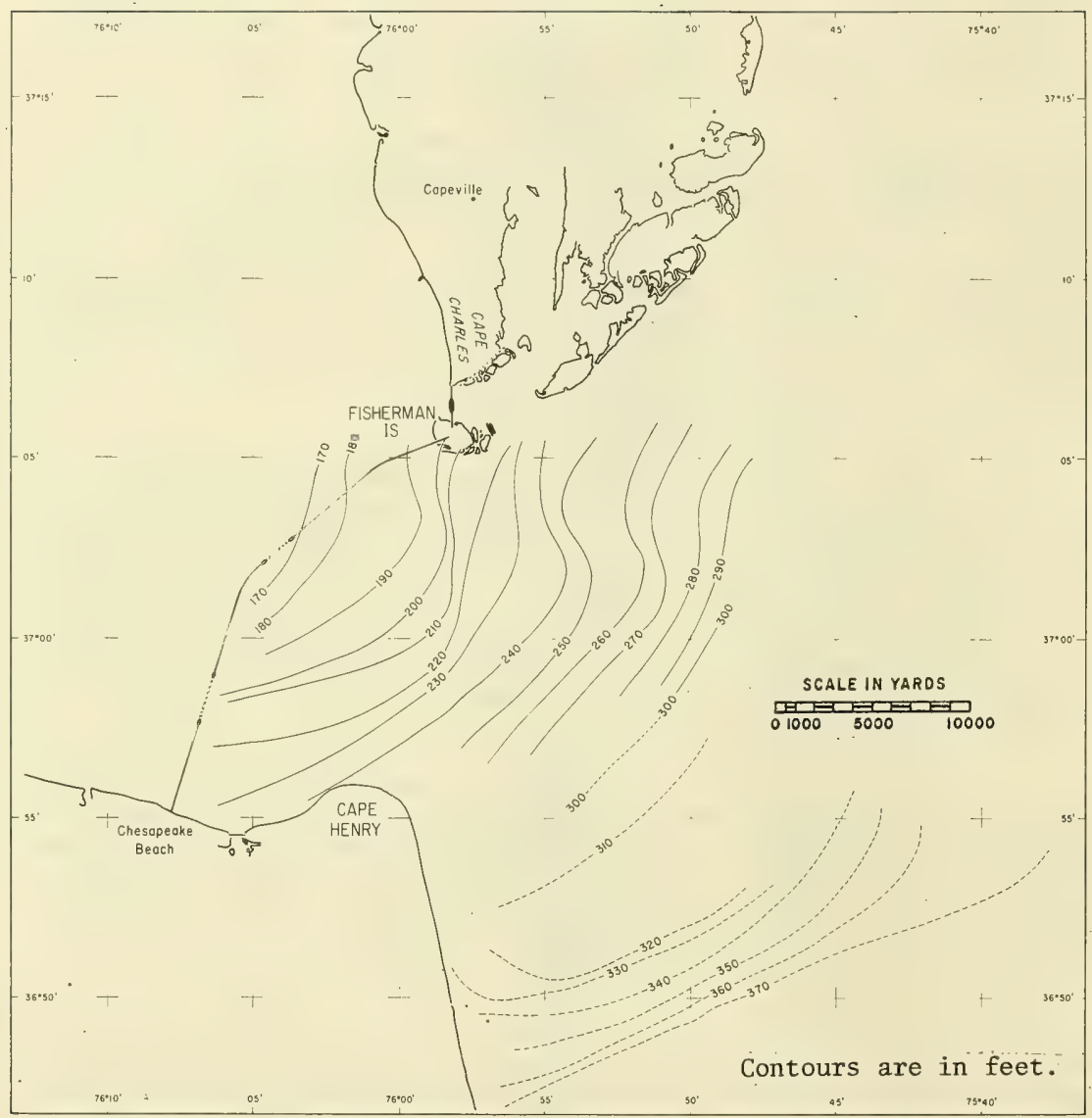

Figure 5. Contours on a reflector within the presumed Miocene section underlying the study area. 
more-or-less parallel the key reflector. Since the key reflector dips below record coverage at the south margin of the entrance area grid lines (Figure 2), it is too deep to appear on records from the reconnaissance area off Virginia Beach. A hypothetical position of this reflector in the reconnaissance area was constructed by selecting a higher reflector within the evenly bedded section from records near the south margin of the grid, mapping this higher reflector through the reconnaissance area to the south, and applying the depth difference between the higher and lower reflector measured in the area of overlap.

The major erosion surface is sharply defined in places by a strong reflector; however, in many areas it can only be approximated because of masking by overlying reflectors or deficient acoustic contrast across the boundary. Despite these deficiencies enough information is available for tentative mapping (Fig. 6). This mapped system may be continuous with the ancient drainage system described by Hack (1957), Harrison (1963), and Harrison et al (1965).

The largest channel (Channel A, Figure 6) is believed to be continuous with the presumed ancestral Susquehanna, described by Harrison et al (1965) from the region just north and west of the study area. The maximum depth of the thalweg in this valley is not clear because the central portion of the valley is obscured on reflection records. This is due to an acoustically opaque stratum which lies above and apparently follows the thalweg. Unless a gorge exists below the opaque layer the maximum projected depth is probably less than $-200 \mathrm{ft}$. MLW. In this connection, Beckmann, Drake and Sutton (1961) concluded from seismic reflection data at the Bridge-Tunnel crossing that no channels in the subbottom extended deeper than -150 feet; Harrison et al (1965) found channeling to a depth of -160 feet MLW below the Bridge-Tunne1, and McLean (1966) indicates that Pleistocene sediments reach a depth of at least -185 feet MLW off Fisherman Islands.

Two other channels (B and C) flank and roughly parallel the course of Channel A. Channel B is separated from Channel A by a low divide rising to about -90 feet MLW. Channel C to the east is separated from Channel A by a high broad divide rising to -50 feet MLW. Both Channels $B$ and $C$ have maximum thalweg depths of around 120 to 130 feet within the study limits.

A fourth channe1 (D) crosses under the Bridge-Tunnel near its south terminus at Chesapeake Beach. This channel has a thalweg depth of -130 feet MLW and was considered by Harrison et a1 (1965) as possibly an ancestral channel of the James River. Because of the sonic attenuation attributed to organic content in a thick silt blanket covering most of Lynnhaven Roads, subbottom reflections were not obtained on most of the seismic profiles covering the study area south of Thimble Shoals Channel. As a consequence alignment of Channe1 D east of the Bridge-Tunnel has been inferred largely from core and boring evidenence. Channel D appears from the Bridge-Tunnel borings 


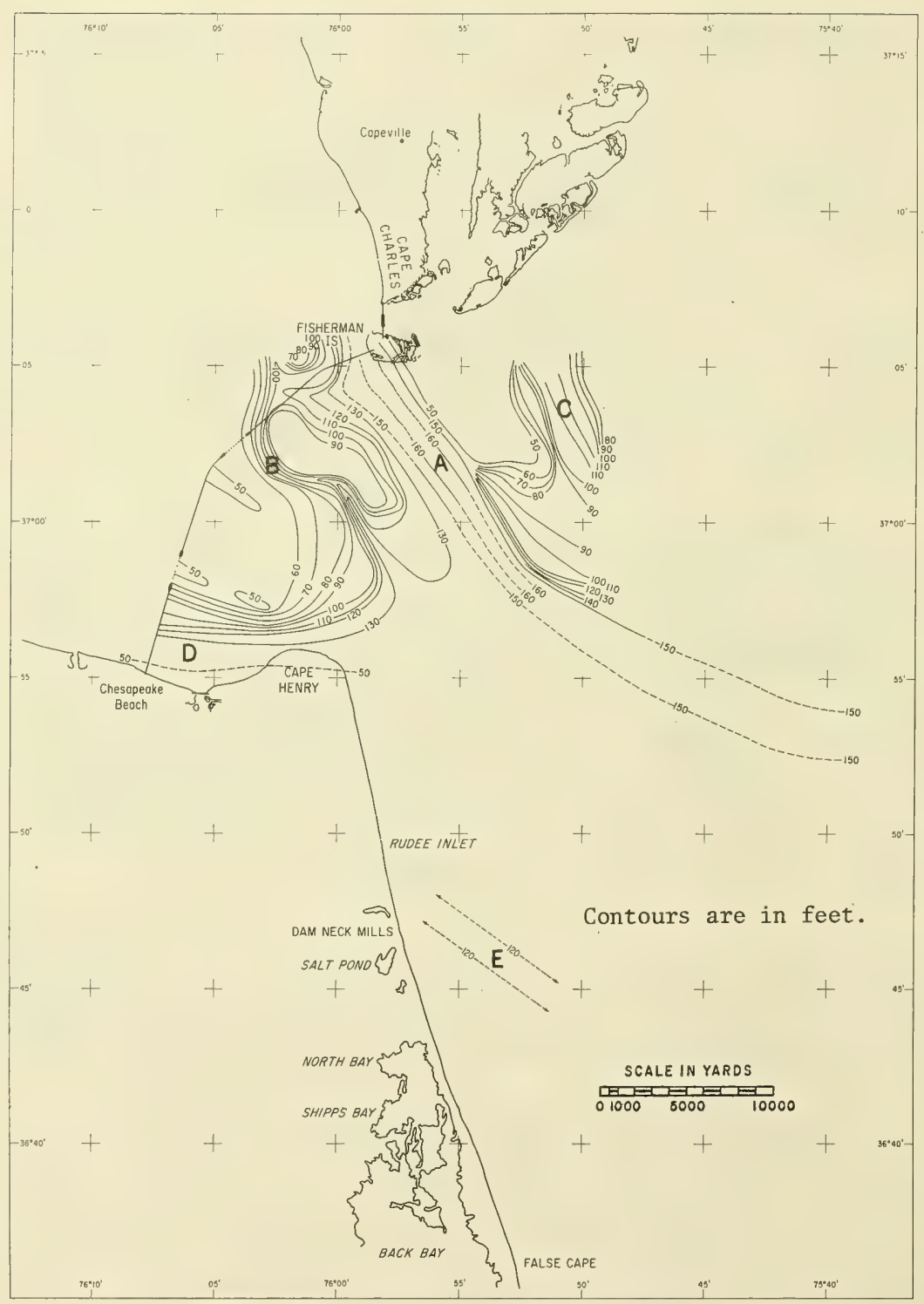

Figure 6. Contours on the buried erosion surface underlying the study area. 
to have cut through sediment unit $\mathrm{E}$ and well into the underlying F-G units. Several cores in Thimble Shoals Channel recovered material at less than -60 feet MLW associated with the E unit and two (C 34 and $C$ 42) penetrated to an underlying silty sediment regarded as probably continuous with the F-G unit. On this basis and support from the Bridge-Tunnel data, a high in the erosion surface near Chesapeake Channel has been extended southward under Tail of the Horseshoe to Thimble Shoals Channel.

The only reliable geophysical line between Chesapeake Channel and Thimble Shoals Channel is line D-E which shows a continuous reflector at less than -60 feet MLW crossing under Tail of the Horseshoe. This reflector is consistent with the core data. However, a second strong reflector dips southward from a high point near the sediment surface at Chesapeake Channel to a depth of 130 feet just south of Thimble Shoals Channe1 where subbottom penetration was lost. This second reflector may represent an erosional unconformity in the presumed Miocene sediments below the erosion surface delineated by Harrison et al (1965) and on Figure 6, or it may actually be continuous with the erosion surface mapped to the north. If the latter concept is true, the channel as based on the deeper reflector of line D-E and a discontinuous, apparently associated reflector visable on parts of lines 4 and $M$ in the Lynnhaven Grid would be much wider and include the small channel shown on the Bridge-Tunnel section north of the larger Channe1 D. The probably trend of this larger channel would be southeast rather than east and it would pass under the south Bay Shore between Lynnhaven Inlet and Cape Henry.

Since firm data on alignment are not available, the interpretation of Channel D as shown on Figure 6 is based on the core and boring data with Channe1 D trending eastward between the high under Tail of the Horseshoe and the land area to the south where Oaks (1964) interpreted the Miocene surface 1ying generally at less than -50 feet MLW. This seems the most reasonable explanation based on the meager data at hand.

Reflections from fill in the various channels is characterized by the common occurrence of high angle bedding surfaces especially in the large $A$ and D Channels. On some records no stratification or bedding is apparent in the valley fill although cross 1 ines run on a,perpendicular heading clearly show bedding. Possibly reflectivity is enhanced or diminished by the relative angles between the survey track and the dip of the beds. It may also be that the bedding is not unidirectional but that only certain sets have reflective interfaces. Wherever these bedding surfaces have been detected, they were found to dip southwestward, thus they lie almost normal to the axis of the southeast trending A Channel and dip slightly upstream in the D Channel.

The fill is thickest where the valleys are deep, but it appears to extend across the low interfluve between the $A$ and $B$ valleys where it thins to only a few feet. Even in this thinning section internal 
bedding, dipping southwestward is stil1 apparent. In the deeper parts of Channel A the bedded fill overlies earlier fill of indeterminate thickness.

A large channel reaching thalweg depths of about -180 feet MLW was crossed by two closely spaced Virginia Beach reconnaissance 1ines. The approximate position and alignment of the channel is shown on Figure 6 by the mid-depth contours of -120 feet MLW and designated ChanneI E. There is insufficient data presently available to detail the channel and other features of the buried erosion surface off Virginia Beach.

4. Sediment Characteristics and Distribution

Much of the data on the character of sediments in Chesapeake Bay Entrance was obtained from 57 cores taken for this study. These 4-inch diameter cores range from 2 to 20 feet long and provide fairly dense coverage of the surveyed area (Fig. 2 and 15). Additional data on surface and subbottom sediments within study limits were obtained from studies of grab samples and short cores by Ryan (1953), engineering boring data reported in Christians and Meisburger (1967), and chart notations on U.S. Coast and Geodetic Survey charts. Detailed coverage of surface and subbottom sediments along the track of the Chesapeake Bay Bridge Tunnel (at the western border of the study area) are contained in logs of engineering test borings made during foundation studies for that structure (Chesapeake Bay Bridge Tunnel Commission, 1961). A number of cores obtained for a dredging study by the Norfolk District, Corps of Engineers, in 1970 are within this study area and have been made available for study. These cores are plotted on Figure 2.

The dominant surficial sediment of Chesapeake Bay Entrance is a homogeneous (Figure 7) gray, fine to very fine quartzose sand, usually well sorted and often silty. This fine sand body mantles the bottom almost everywhere within the study limits, (Figs. 8 and 9) except the channels and Lynnhaven Bay where gray silt is the dominant sediment type. Medium and coarse sand is rare; the only sizable concentration at the surface occurs in Thimble Shoals Channel where a light brown to reddish-brown coarse sand with streaks and patches of gravelly sand occur in outcrops (Figures 10 and 11). Smaller concentrations occur in thin patches on the gray sand blanket and on the southwest rim of Chesapeake Channel.

of the 57 cores taken for this study and 8 additional cores and borings otherwise available from the study area (Christians and Meisburger, 1967 Norfolk District Dredging Survey, 1970), on1y 11 contain surface sediments with a mean diameter coarser than fine sand (.250 mm - $2.0 \mathrm{phi})$. Six of these cores are closely grouped in Thimble Shoals Channe1 (C33, 34, 42, 45, 48, DH4) within an outcrop area of the type $\mathrm{E}$ sand and gravel previously discussed in connection with the Bridge-Tunnel boring data (Figures 2 and 4 ). Core 51 on the north edge of Tail of the Horseshoe is judged to be in a small outcrop area of the same unit which is continuous under the shoal. 


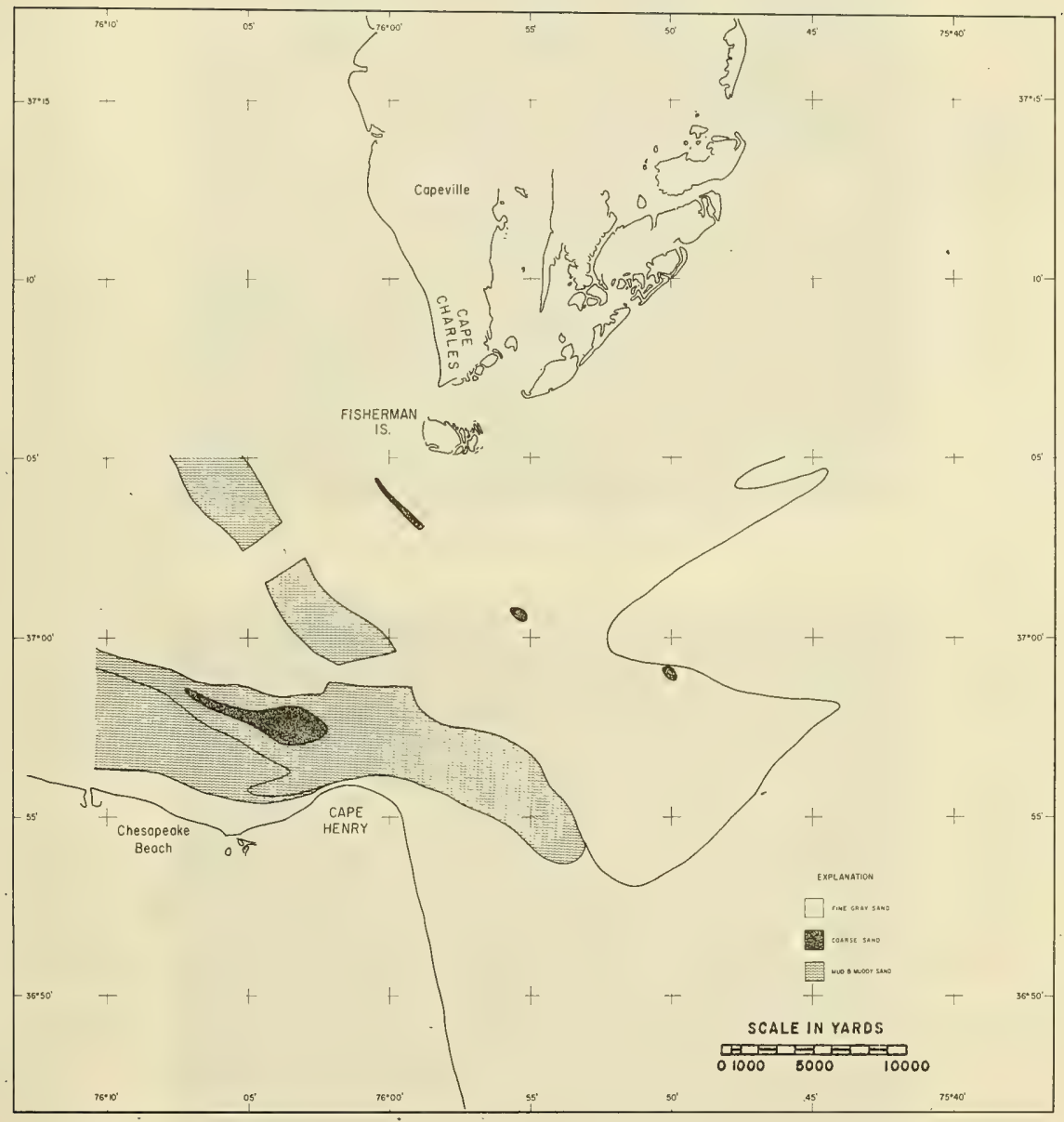

Figure 7. Surface sediment distribution in the study area based on gross characteristics. 


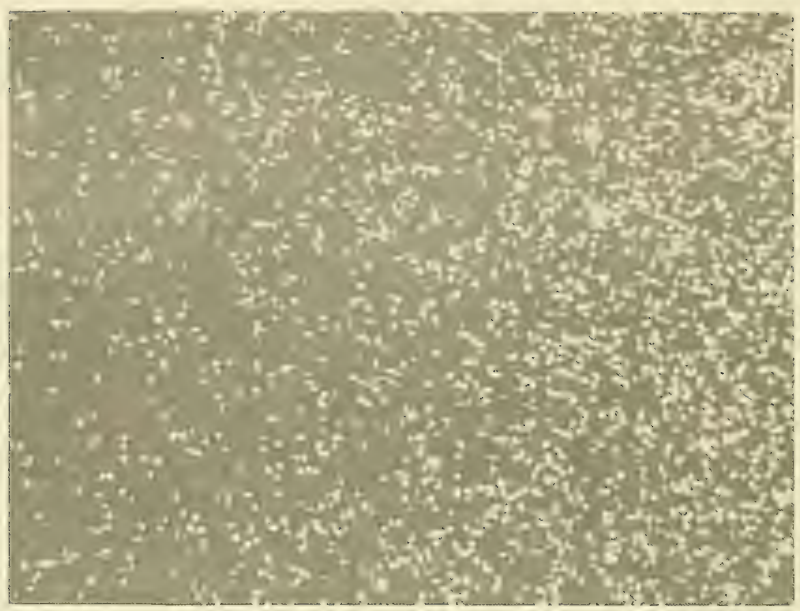

CORE 40-9 inches

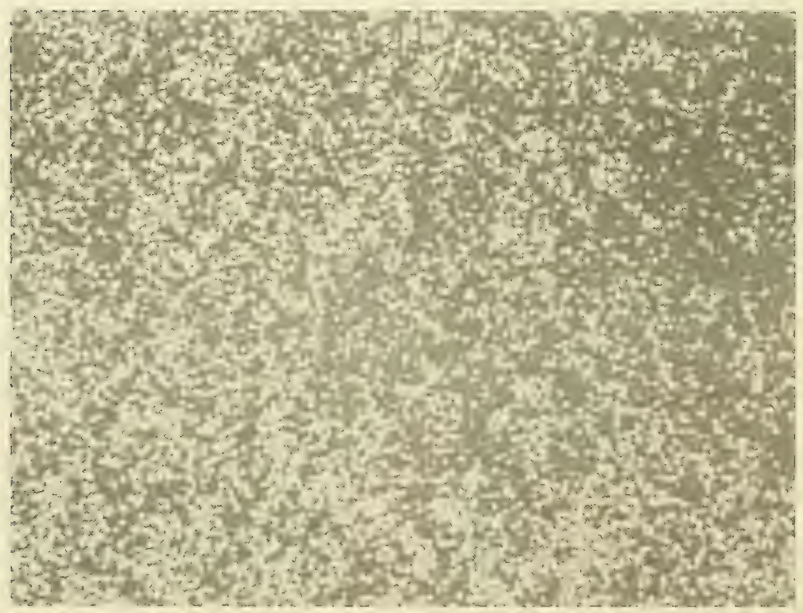

CORE 57-81 inches

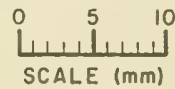

Figure 8. Typical fine gray sand (Unit A) from Chesapeake Bay Entrance. 


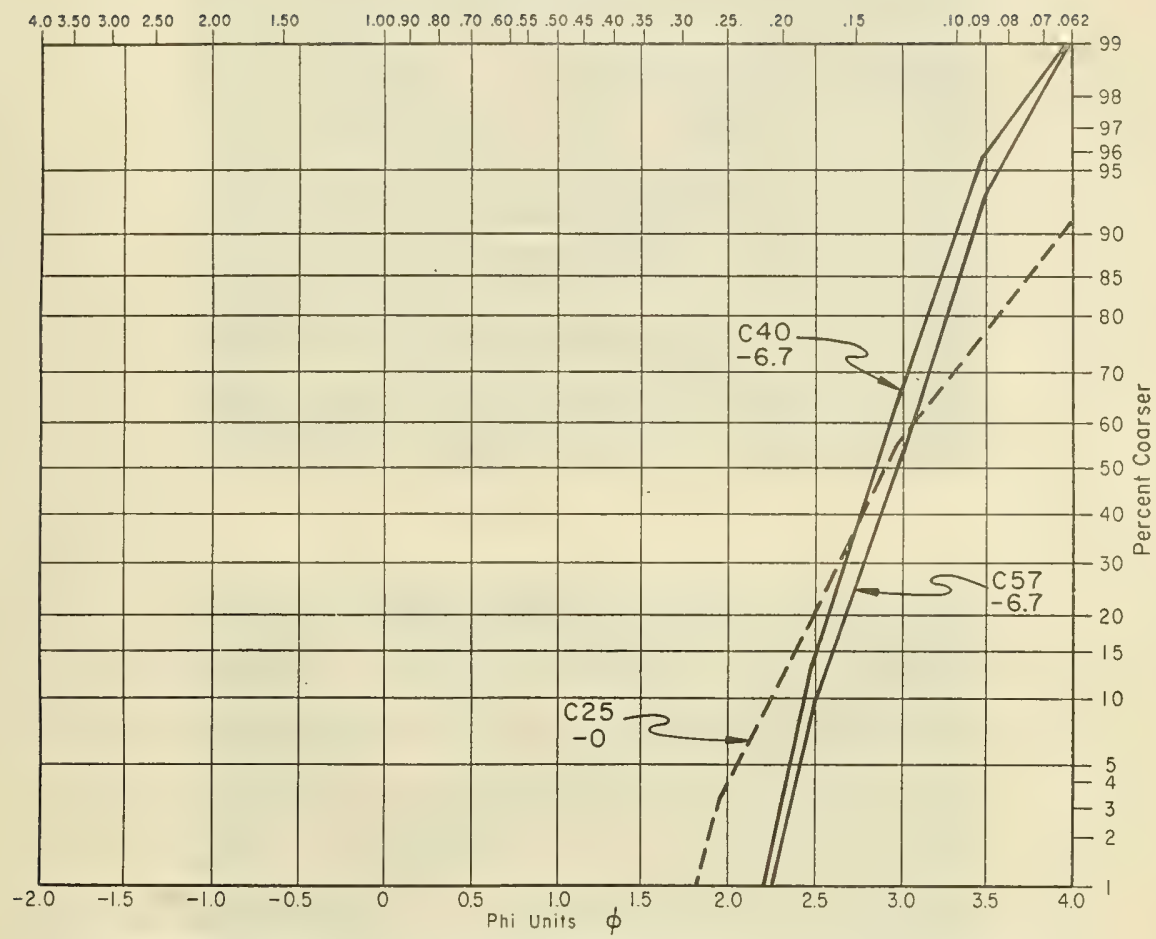

\begin{tabular}{|l|l|l|l|l|l|}
\hline GRANULE & VERY COARSE SAND & COARSE SANO & MEDIUM SAND & FINE SAND & VERY FINE SAND \\
\hline
\end{tabular} WENTWORTH SCALE

Figure 9. Size distribution for typical samples from the fine gray sand (Unit A). 


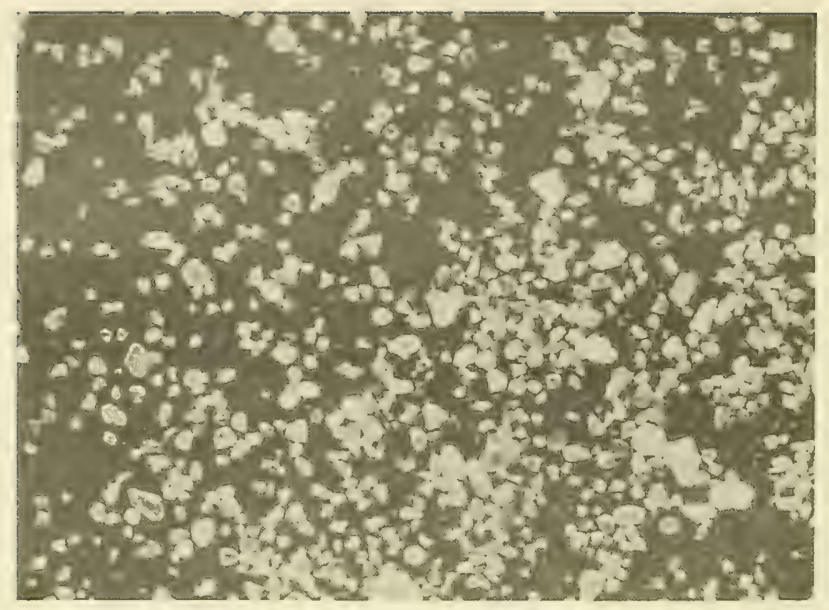

\section{CORE $33-177$ inches}

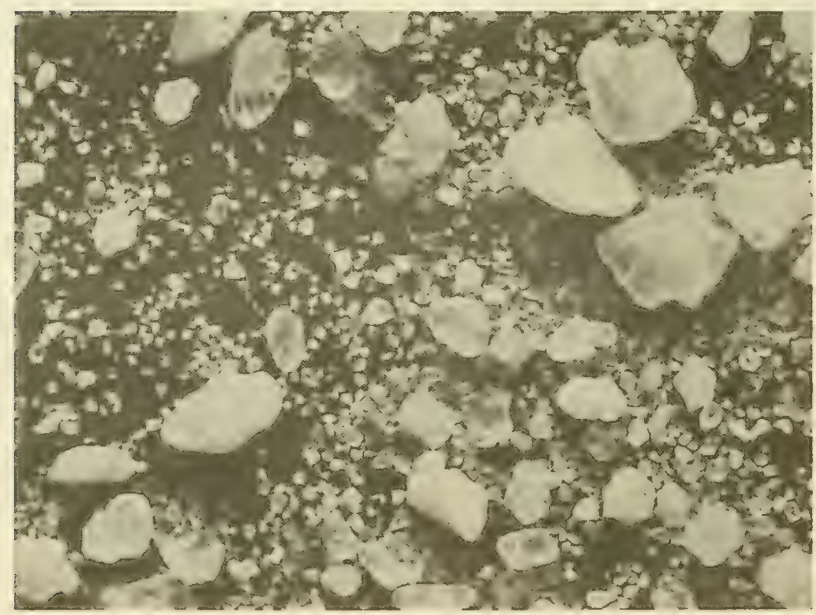

CORE $44-48$ inches

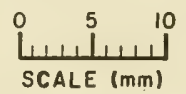

Figure 10. Typical samples of the coarse gravelly sand (Unit E) occurring in Thimble Shoals Channel and under Tail of the Horseshoe. 
SIZE ANALYSIS

Millimeters

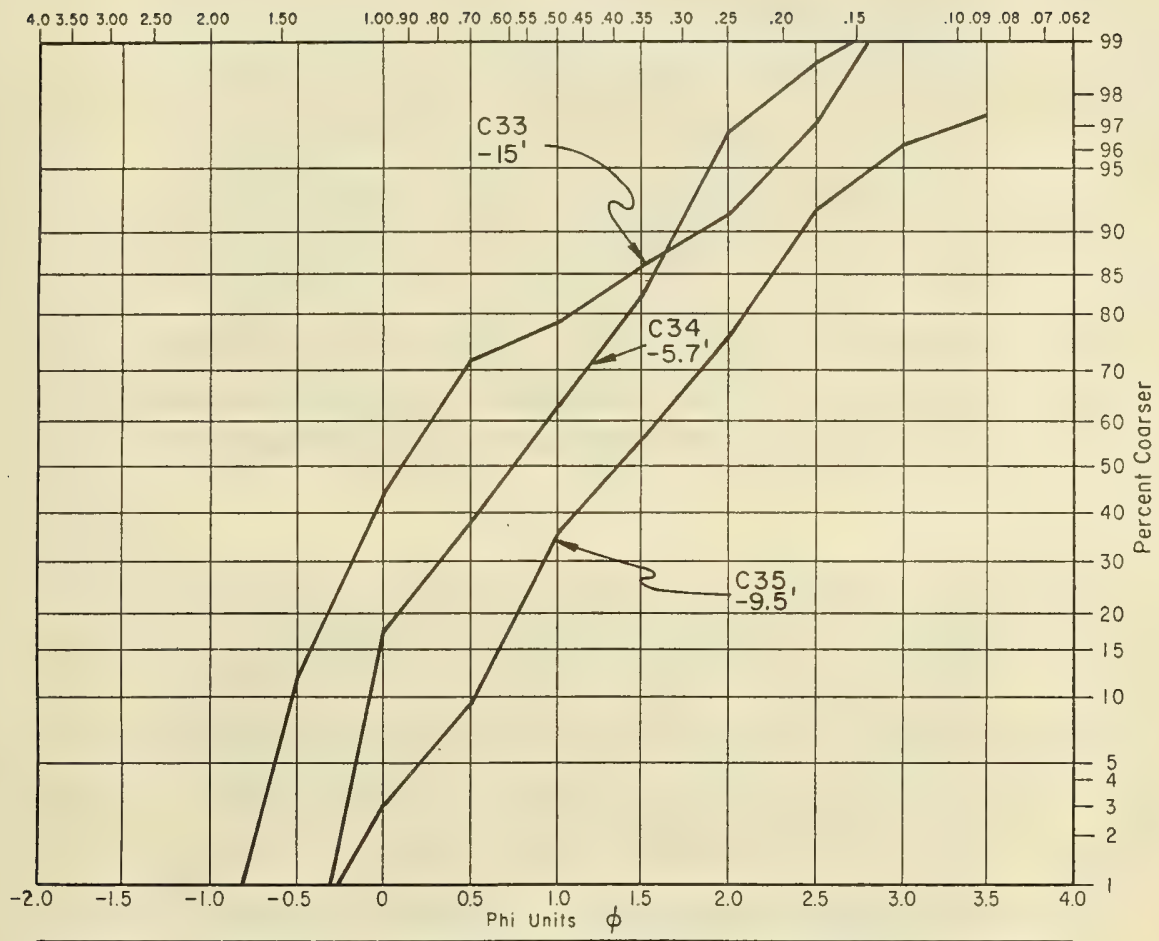

\begin{tabular}{|l|l|l|l|l|l|}
\hline GRANULE & VERY COARSE SANO & COARSE SAND & MEDIUM SAND & FINE SAND & IVERY FINE SAND \\
\hline
\end{tabular} WENTWORTH SCALE

Figure 11. Size distribution for typical samples of Unit E sand. 
The remaining four cores are from the terrace fringing Cape Charles. These cores (C10, 15, 39 and 21) contain a surficial layer 1 to 3 feet thick composed of medium to very coarse, iron-stained, quartzose sand (Figures 12 and 13). The sand is distinctly different in texture and appearance from the underlying and surrounding fine gray sand which is characteristic of the terrace. Unlike other sediments in the study area these brown sands contain a significant content of she11s and she11 fragments, mostly surf clams (Spisula) and razor clams (Ensis).

Two of the cores on Cape Charles terrace containing coarse brown sand (C10 and 15) lie close together on the rim of a large semi-closed depression off Fisherman Island. Geophysical records across the core sites show that these cores were taken in an area of sand waves 3 to 8 feet high. Ludwick (1970) recently reported on these sand waves and noted that coarse brown sand occurred in the area. He suggests that the sand may be relict. Core 39 is from the flank of a peaked symmetrical feature about 10 feet high which may be a solitary sand wave. Core 21 was retrieved from a relatively featureless area of the terrace.

The fact that the coarse brown sand in the cores from Cape Charles terrace all appear to be identical and the cores are in line northeastsouthwest suggests that the sand may be continuous between core sites. If so the sand occurs in a narrow band as cores to either side of the Iine contain fine gray sand.

The thickness of the fine gray sand covering most of the study area is generally greater than the penetration of cores made for this study. Deeper borings made along the Chesapeake Bay Bridge-Tunnel show this deposit reaches a maximum thickness of 120 feet near Fisherman Island and has an average thickness of more than 10 feet.

This sand is remarkably uniform in texture and appearance. The mean diameter of 95 samples obtained from cores in the deposit at various depths from the water-sediment interface to 12 feet downhole range from .098 to $.216 \mathrm{~mm}$ (3.35 to 2.08 phi) with a standard deviation of .25 phi (Figure 14).

Most of the gray sand samples are well sorted. There is no pronounced size differences between samples from shoals and depressions on Cape Charles terrace, probably a result of the uniformity in available sand rather than uniformity in the distribution of wave and current energy over the terrace area.

A sharp lithologic break occurs in cores from the south slope of Tail of the Horseshoe where the medium to very coarse sand and gravelly sand exposed in Thimble Shoals Channel is thinly buried by fine gray sand near the outcrop line. Except for cores penetrating to this coarse stratum few cores in the study area show sharp 1ithologic contrast in vertical section. 


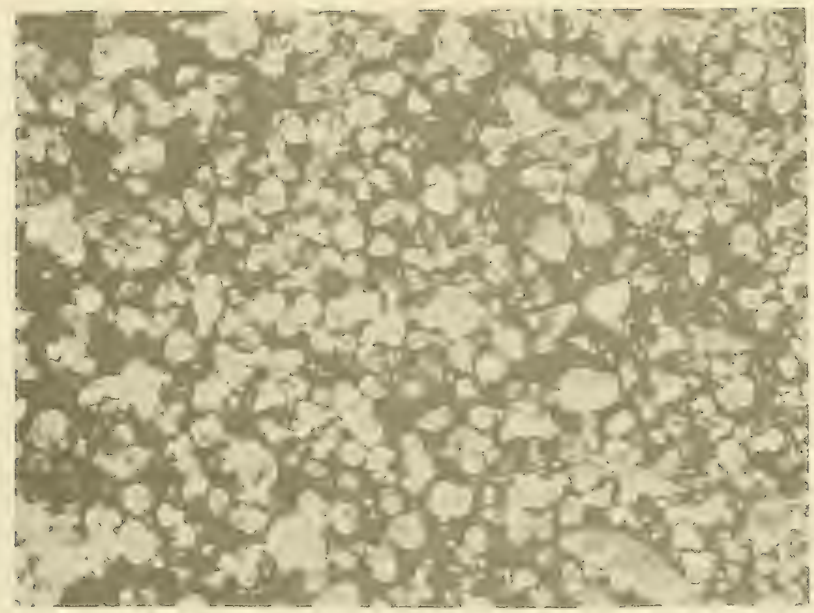

CORE 15 TOP

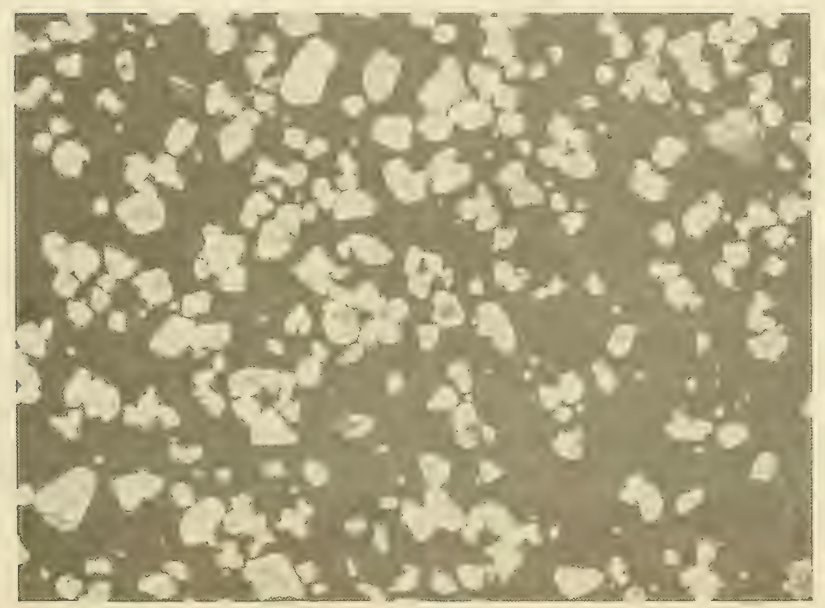

CORE 39 TOP

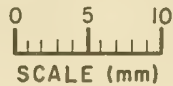

Figure 12. Photos of typical samples from the coarse, brown, shelly sand occurring in patches on the Cape Charles Terrace. 


\section{SIZE ANALYSIS}

Millimeters

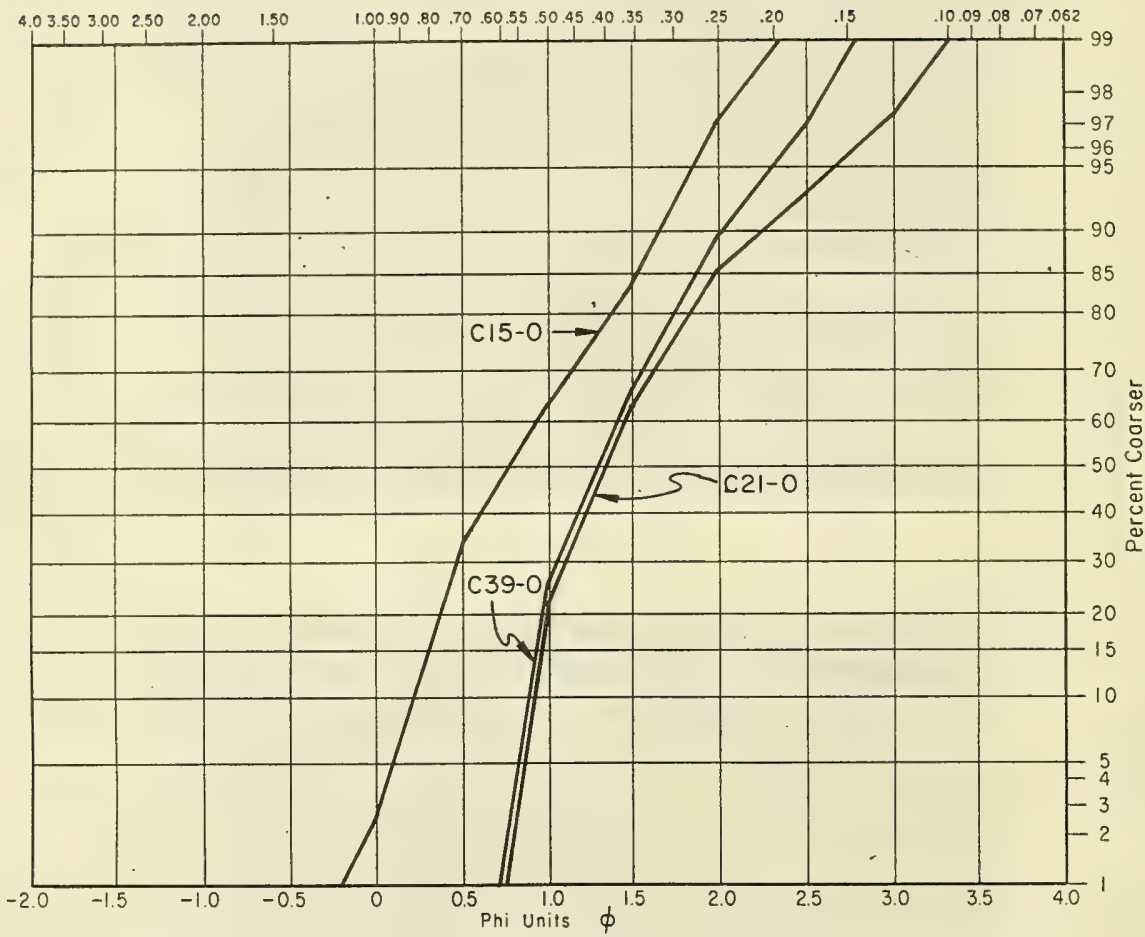

\begin{tabular}{|l|l|l|l|l|l|}
\hline GRANULE & VERY COARSE SANO & COARSE SAND & MEOIUM SAND & FINE SAND & VERY FINE SAND \\
\hline
\end{tabular} WENTWORTH SCALE

Figure 13. Size distribution curves for typical samples of the coarse, brown, shelly sand occurring in patches on the Cape Charles Terrace. 


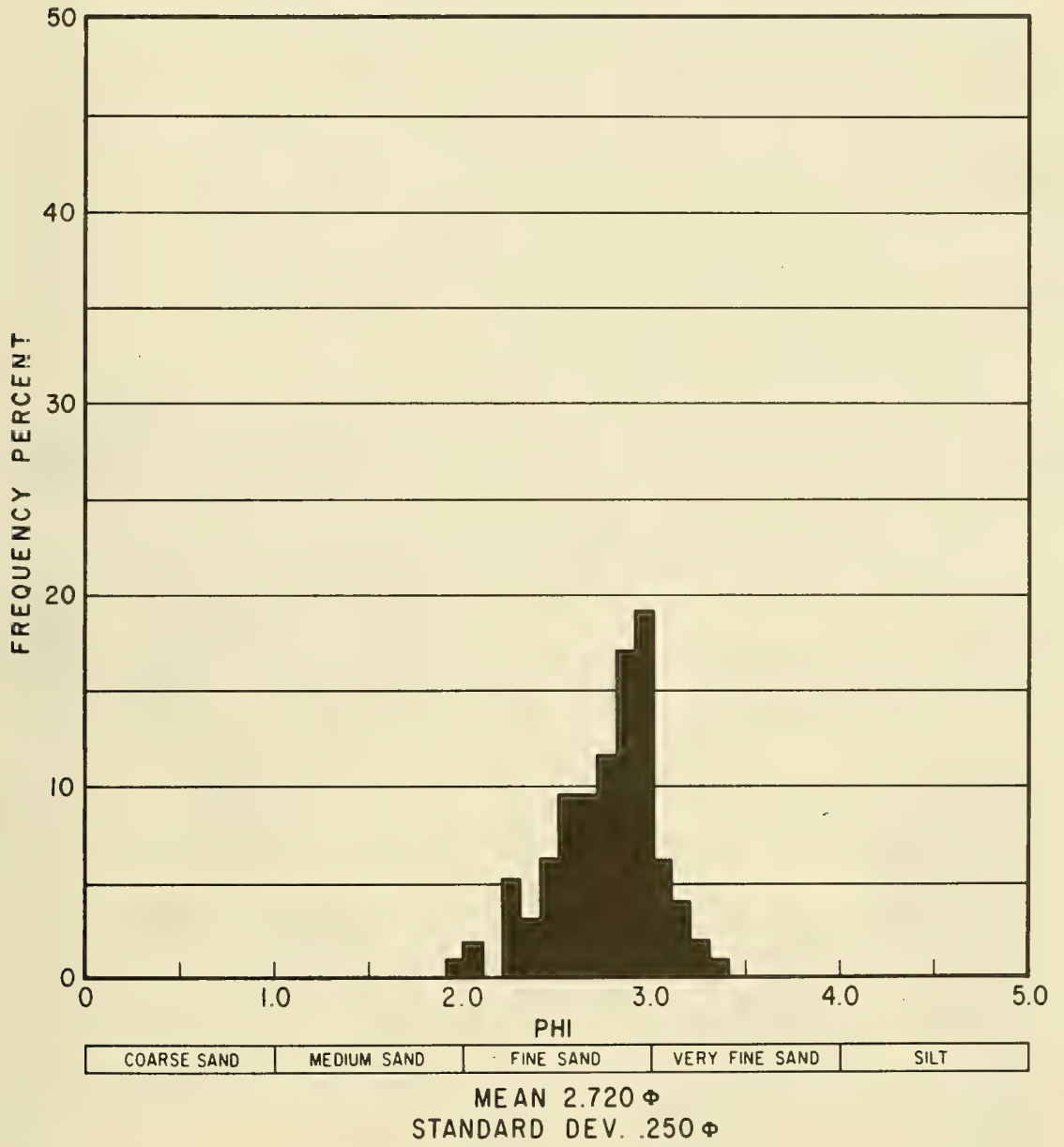

Figure 14. Histogram of the phi mean diameter of 95 samples from cores in the fine gray sand (Unit A). 
Figure 15 is an isopach map showing sediment thickness over a reflective horizon called the blue horizon. The isopach reflector surface is more or less level and dips slightly southward. Where it appears, the blue horizon is generally the uppermost clearly definable reflector. The irregular to smooth appearance of the blue horizon suggests that in places it follows an erosional surface and elsewhere lies along a depositional surface. Though acoustically weak or entirely lacking in places, the blue horizon is believed to be present throughout the study area as a zone or interface separating sediments of different physical properties. Cores and borings for the Chesapeake Bridge-Tunnel indicate that the blue horizon is probably near or at the base of the ubiquitous fine gray sand blanket (Type A) covering most of the study area.

West of Channel A (Fig. 6) data from outcrop, cores, and BridgeTunnel borings indicate that the isopach reflector generally overlies finer sediments (Types B,C,D,F,G) or coarse sand (Type E). East of Channel A, information on underlying sediments is deficient because few cores in this area penetrated the upper sand blanket; however, variation in acoustic contrast along the blue horizon and the partly erosional, partly depositional, appearance of the interface suggest that underlying sediments are variable in physical properties.

Based on the Figure 15 isopach map, the total volume of sediment above the isopached (blue) reflector within study limits is estimated to be $1.8 \times 10^{9}$ cubic yards. 


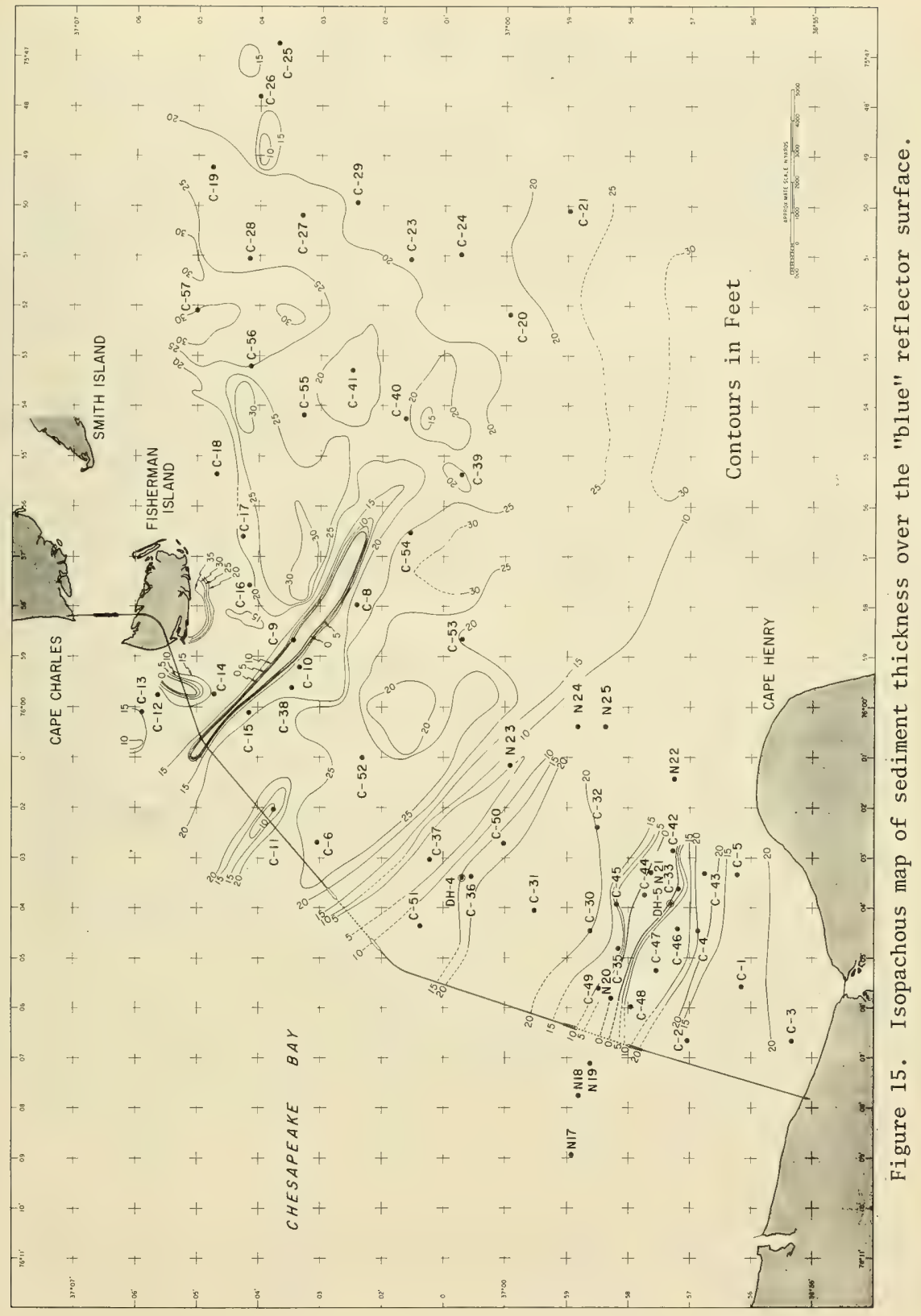


Miocene strata of the Chesapeake Group underlie the entire study region and can be correlated at the group level throughout. In we11s on southern Delmarva Peninsula, and on the southeastern Virginia coastal plain the top of the Miocene has been assigned a Yorktown age (Sinnott and Tibbetts 1957, Oaks and Coch 1965, Oaks 1964, Harrison et al 1965). Miocene sediments penetrated by Bridge Tunnel borings near Chesapeake Channel are considered to be no younger than St. Marys age by McLean (1966) indicating that Yorktown sediments were either eroded from this area or never deposited.

Several CERC cores in the vicinity of Thimble Shoals Channel are judged to have penetrated to the Miocene surface on the basis of lithologic correlation with nearby Bridge-Tunnel borings; no fossil evidence was obtained in these cores. Core 36 near Chesapeake Channe1 (Figure 2) penetrated material containing well-preserved, unworn macrofossils of definite Miocene Age but uncertain formational affiliation.

Post-Miocene deposits of the southeastern Virginia Coastal Plain have been described in detail by Oaks and Coch (1963) and Oaks (1964). Post-Miocene stratigraphy under the southern Delmarva Peninsula has not been detailed, and known deposits are assigned to the Pleistocene Columbia Group undifferentiated.

No direct relationship between post-Miocene sedimentary units in the study area and those described from the adjacent land areas of southern Delmarva Peninsula and southeastern Virginia can be shown. If such a relationship exists, it seems most likely to be between the coarse gravelly sand (Unit E) outcropping in the study area at Thimble Shoals Channel, the lithologically similar gravelly sands occurring in Columbia Group deposits on southern Delmarva Peninsula, and gravelly sand occurring in the lower member of the Great Bridge Formation (P1eistocene) under the southeastern Virginia Coastal Plain (Oaks 1964). Other gravel bearing units in the southeastern Virginia coastal plain: the Kilby facies, Bacons Castle Formation; members of the Norfolk Formation; the Kempsville Formation and Londonbridge Formations are possible correlatives of Unit E. However the Kempsville and Londonbridge Formations are not known to occur lower than -17 feet MSL nor to directly overlie the Miocene surface while Unit E occurs as deep as -90 MSL and characteristically overlies an eroded surface in Miocene strata. The Bacons Castle Formation has not been identified east of Suffolk Scarp which lies several miles west of the study area. The Norfolk Formation containing gravelly members and found as deep as -35 feet MSL is a possible but less likely correlative to unit A than the Great Bridge.

Because of the coarse character of Unit $E$ sediment and its apparent relationship to buried stream channels, it is believed to be a relic of lower sea level; thus late Wisconsin glacial or earlier in age. Unit D peat which occupies with Unit E the same stratigraphic horizon on the 
exoded surface of underlying Miocene strata has radio carbon ages placing it in the time frame of the Holocene transgression. (Harrison et a1, 1965).

Since borings do not show any points of overlap between units D and $\mathrm{E}$, their relative age cannot be determined; it is possible that both are of the same age. However the coarse, poorly sorted texture and absence of marine she11s in most unit E material suggest a fluvial origin and the heavy iron stains indicate subaerial exposure, which point to a time of origin at least predating the local onset of the Holocene Transgression.

Sediment units A, B and C which overlie the dated peat horizon D (Harrison et al 1965) are clearly of Holocene age and are judged to include both transgressive and post transgressive facies. Studies of microfossils from the soft silty units B and $C$ have been made by McLean (1966) using bridge tunnel samples and Nelson (1969) and Nelson and Meisburger (1972) using CERC cores. Both studies indicate that the units were formed in fresh to brackish shallow water environments. A carbon-14 age of 11,500 yr BP +1200 yr on organic detritus sampled from 9 to 12 foot downhole on CERC Core 37 (Maynard Nichols, personal communication), indicates a transgressive Holocene age for this material judged to be a part of Unit B.

Based on radioactivity dating of peat in underlying B and D sediment units it is clear that the fine gray sand of unit A is of Holocene age. Evidence suggests that at least part of the unit is post-transgressive (i.e., since relative sea level reached its present position).

Study of microfossils from CERC cores, in unit A showed species adopted to the environment presently existing in the area (Nelson 1969, Nelson and Meisburger 1972). In addition, the top of unit A averages only about -20 feet MLW and locally rises to and slightly above sea leve1. Reworking or post depositional uplift could also account for the present elevations of the unit, and a Holocene uplift has been postulated by Harrison et al (1965), but deposition at relative sea level near that of the present time seems the most probable explanation.

The silt deposit in Lynnhaven Bay may be post-transgressive, thus not directly related to unit $B$. The Lynnhaven silt appears to have been laid down in deeper water than most of unit B (Nelson 1969) and it lies at a shallower depth.

The erosion surface plotted from seismic reflection data in Figure 6 is judged to correspond with the top of the Miocene in the area to the south and west of the northeast wall of Channel A which cuts diagonally beneath the Entrance Area. Only a small segment of the BridgeTunnel complex lies north of Channe1 A (Figure 6) thus subbottom 1ithologies below the penetration range of CERC cores is obscure. According to Bridge-Tunne1 borings, the top of the Miocene is truncated at the steep north wall of Channel A about 40 feet below the top of the wall 
(Figure 4, App.A, Lines C and 11). The erosion surface mapped on Figure 6 to the north and east of Channel A is underlain by about 30 feet of post-Miocene sediment deposited prior to the cutting of Channe1 $A$ and is thus probably older than late Wisconsin. In the area enclosed by the north wall of Channel A, the Bridge-Tunnel and the south Bay shore, this older deposit appears to have been largely if not entirely removed by the various channels and the erosion surface as depicted in Figure 6 is considered to be essentially at the top of the Miocene. With the exception of Unit $E$ which may possibly be a relic of the post-Miocene but pre-erosion surface deposit, the fill over the Miocene surface south and west of Channel A is entirely Holocene.

Ryan (1953) estimated that a volume of $46.4 \times 10^{9}$ cubic yards of sand would be needed in the southern Bay area to fill the old Pleistocene channels to an extent consistent with present bathymetry. He concluded from these estimates that the sediment produced or contributed to the Bay since its invasion by the Holocene seas was not sufficient to account for this fill plus the $14.75 \times 10^{9}$ cubic yards of fill estimated to have been deposited in mid-and upper-Bay locales. A contribution of sediment from the Atlantic Ocean to the lower Bay was thus considered probable.

Although Ryans' estimate of channel depths in the Bay Entrance did not take into account the possible Holocene uplift later postulated by Harrison et al (1965) which would reduce needed fill in the lower Bay, the volume still needed to fill the uplifted channels coupled with the fact that the old channels in mid-and upper-Bay are only partially filled while they are almost entirely buried in the lower Bay, strongly suggests a sediment influx into the lower Bay from the ocean side.

The Pleistocene Channels in the Bay Entrance area (Figure 6) have been filled for the most part with fine silty sediment of units $B$ and $\mathrm{C}$ deposited in a shallow brackish to fresh water environment (Harrison et al, 1965; McLean 1966, Nelson, 1969, Nelson and Meisburger (1972). This deposition presumably took place during the most recent transgression as the former stream channels were being progressively embayed. It is probable that the bulk of these fine sediments were brought down by the parent streams to come to rest in the embayed esturaries. However the persistent southwest dip of bedding planes in the channel fill detected on seismic reflection profiles (Appendix A) suggests that depositional control and possibly the immediate sediment source may have been to the northeast of the Entrance area. It is possible therefore that the preponderance of unit B and C sediments were swept across the area from the ocean side to aggrade the old channels while the sediments and processes internal to the channels exerted only minor influence on the filling process.

The fine gray sand (unit A) which comprises the surface and near surface deposits on the terrace surrounding Cape Charles and surmounts the Horseshoe - seems very likely to have originated from sources 
outside the Bay area. The very shallow shoal tops and apparent occurrence of this sediment above sea level at Fisherman Island in addition to a microfauna adapted to present conditions in the Bay Entrance (Nelson 1969), indicate deposition of at least the upper part of this unit at or above existing relative sea level.

Present sources of sand-size sediment bayward of the deposits in the entrance are largely to be found on the western shore of the Bay area where shore erosion and main-stream drainage are estimated to have produced the bulk of post-transgressive Bay sediments (Ryan 1953). If type A sand in the Bay Entrance is largely of post-transgressive origin, it is unlikely that the source area is in the western Bay because the western Bay sands grade finer toward the inner bay, and the deep central Bay channel is mud-floored (Ryan 1953); thus, no avenue of present large scale transport between the western shore and the entrance area is apparent.

Transport of sand from the eastern shore of the Bay to the entrance area seems a more feasible route, but sand production on the eastern shore is relatively small and probably inadequate to account for the large volume of Type A sand present around the entrance area.

Further evidence of a possible seaward origin for the fine gray sand body is a contrast in percentages of some heavy minerals contained in the Bay Entrance area sands to percentages of the same minerals in other Bay areas. Of the 78 samples from the Bay area examined for heavy minerals by Ryan (1953) 13 were in the fine gray sand body south and west of the Cape Charles area. In these 13 samples hornblende ranged between $19 \%$ and $52 \%$ of the total heavy fraction; hornblende exceeded $19 \%$ in only 9 of the 65 samples from elsewhere in the Bay. Chlorite ranged from 4 to 38 percent in samples from south of Cape Charles, but was only 1 percent or less in samples from west of Cape Charles and elsewhere in the Bay area. Black opaques which are generally $25 \%$ to $60 \%$ of the total heavy fraction in most Bay samples, are less than $10 \%$ in all but 4 of the samples from the gray sand blanket.

Since the fine sand flats around Cape Charles contain a size range that is not common elsewhere in the Bay, the differences in percentage of hornblende, chlorite and black opaques may be due to a preferential association of these minerals with the dominant size mode of the sand. However, the degree of difference in size with some large areas of sand in the Bay is not great, and the percentage difference in the content of these minerals is substantial.

Pleistocene and Holocene events have been the dominant influence in shaping the present bottom and shallow subbottom characteristics of the Bay Entrance. Repeated erosion of underlying Miocene strata occurred as a consequence of low sea level stands during Pleistocene glacial epochs. 
During interglacials, the sea repeatedly invaded the region leaving a series of marine, and marginal marine deposits. Many of these deposits are preserved on the southeastern Virginia coastal plain (Oaks, 1964), but with the possible exception of Unit E no Pleistocene deposit in the area southwest of Channel A (Figure 6) appears to have survived late Wisconsin erosion. On the broad high between Channels A and B, a section of Pleistocene sediments apparently remains between the Miocene surface and the erosion surface mapped in Figure 6.

During much of Holocene time this upland would have formed a southward extension of Delmarva Peninsula restricting the Bay mouth to the area occupied by Channels $A$ and D (Figure 6). If the Holocene uplift postulated by Harrison et al (1965) is taken into account, the relative rate of sea level rise in Chesapeake Entrance must have been very slow; consequent1y conditions changed only slightly from the onset until about 5,000 years BP when drowning of the upland between channels A and $B$ opened the Bay mouth.

If the foregoing is a true representation of the Holocene advance, then fill in the Pleistocene Channels probably could not have originated with the advance of a sediment mass from the northeast as a 1 and barrier would have existed in this direction until after the time of deposition indicated by radiocarbon dates on material within the fill (Harrison et al 1965, Maynard Nichols personal communication).

The fine gray sand comprising much of the surficial sediment blanket in Chesapeake Bay Entrance probably did not begin to form until after drowning of the upland between Channels A and B since it overlies and extends we11 bayward of this high. Recent work by Ludwick (1970) indicates that the surface layers of this sand mass are being actively formed by currents and waves, and it seems possible that active sedimentation may still be taking place.

Gross bottom morphology in the Bay Entrance is judged to be 1argely due to the accretion of the fine gray sand and little related to events predating its deposition. Little if any topographic expression of the old Pleistocene erosion surface now remains in the Bay Entrance. The major positive topographic features are areas of accretion of the fine gray sand on the sand flat surrounding Cape Charles and over the Horseshoe area. Chesapeake channel and the main entrance channel are the principal negative features. Both appear to be due as much to accretion of sediment masses to the flanks as to scour, the north wall consisting of the southern edge of the sand flat surrounding Cape Charles and the southern wall consisting of sand accreted around Cape Henry and on Tail of the Horseshoe.

Evidence of this can be seen on geophysical records which cross the north wall of Chesapeake Channe1 and the main entrance channel (Appendix A). On Chesapeake Channel records (1ines $\mathrm{E}$ and DE), a 
strong reflector passes under the flanking terrace at or near the level of the channel floor indicating that the channel floor may be continuous with the surface of the older unit underlying the terrace sands. A truncated reflector on the wall flanking the main entrance channel at about -60 feet MLW (lines 8 and $K$ ) suggests that here the channel may be partly the result of erosion and partly the product of upbuilding on the flanks. Core 37 in the Chesapeake Channel and Core 23 near the main entrance channel both show indications of deposition in shallower water than presently exists over the area. Core 37 from 3 to 9 feet downhole contains a foraminiferal assemblage dominated by Arenoperalla mexicana indicating conditions transitional to the present environment (Ne1son, 1969). Below 9 feet downhole, a peaty layer has been established to be a near sea level deposit of transgressive Holocene age (Maynard Nichols, personal communication).

\section{Section IV. SAND RESOURCES}

\section{Sand Volume Requirements}

The major potential sand requirement of the Corps of Engineers in the region is for fill to restore and maintain Virginia Beach, Virginia. Existing and recommended projects call for restoration and improvement of the segment of beach between Rudee Inlet and 89th Street by placing an initial fill of 2.4 million yards of sand. Maintenance will require 133,000 cubic yards annually plus the existing maintenance fill amounting to 163,000 cubic yards annually now furnished by dredging from Ow1 Creek. The total annual maintenance fill is thus 296,000 cubic yards. Initial fill plus annual maintenance fill for a 50 year period will require $17.2 \times 10^{6}$ cubic yards of suitable sand.

2. Sand Suitability and Potential Borrow Areas.

The suitability of borrow sand for beach restoration and nourishment depends on several factors. Important factors are size distribution, composition, and economics of recovery and placement. Borrow material significantly smaller in gradation than the native beach material will probably prove unstable under the wave and current regimen on the beach, and will be rapidly eroded. The most suitable borrow sand is sand having nearly the size characteristics of the native beach material. A desirable composition is one in which the particles are composed of hard inorganic material such as quartz that will not degrade readily in the littoral environment.

Within the limits of study, the collected data indicate that there are only two areas with significant deposits of sand suitable for fill on nearby beaches. The ubiquitous fine gray sand and sandy silt covering much of the bottom of the Bay Entrance contains little usable material because of its fine grain size. 
The most promising deposit crops out in Thimble Shoals Channel and along a reentrant in the south flank of Tail of the Horseshoe. This deposit is a coarse brown to reddish brown sand and gravelly sand (Unit E). Data suggest that the deposit extends to and through the Tail of the Horseshoe shoal to near the south wall of Chesapeake Channel where it decreases to a thin layer. It does not appear to extend northward into the deeper part of Chesapeake Channel. South of the Thimble Shoals outcrop area, the coarse sand body appears to extend under Lynnhaven Roads, but is deeply buried under a silt and silty clay layer. Figure 16 shows the approximate configuration, extent and thickness of Type E sand and gravelly sand in the Thimble Shoals deposit which appears economically recoverable. Within the outlined area, about 3,500,000 square yards of Type E material is exposed, and the volume available in this area is calculated to be $11.9 \times 10^{6}$ cubic yards. In addition, about $7.5 \times 10^{6}$ cubic yards are estimated to be available in the area bordering the exposure with a removal of no more than 5 feet of overburden.

In terms of mechanical stability, the Thimble Shoals material is considered good. Most of the sand grains are quartz which is resistant to mechanical and chemical degradation. Some gravel particles are composed of granitic rock which is partly decomposed. These fragments constitute only a minor fraction of the sediment.

Layers and 1enses of we11-sorted, clean sand closely matching the beach sand occur in the Thimble Shoals deposit. However, the split cores showed that these layers are generally bedded with interspaced coarse sand mixed with gravel and occasional thin clay partings. The material finer than the native sand will be removed from the beach soon after placement, and the coarser particles will tend to remain.

Another possible source of suitable beach fill is the coarse brown surficial sands in the area covered by Cores 10, 15, 21 and 39. Assuming the deposits occur in isolated patches of the approximate extent shown in Figure 9 and average thickness is 3 feet, then about $1.9 \times 10^{6}$ cubic yards of this material would be available. Since data are limited concerning deposits in this area, more detailed study including field data collection would be required to more accurately assess the magnitude of suitable borrow material. 


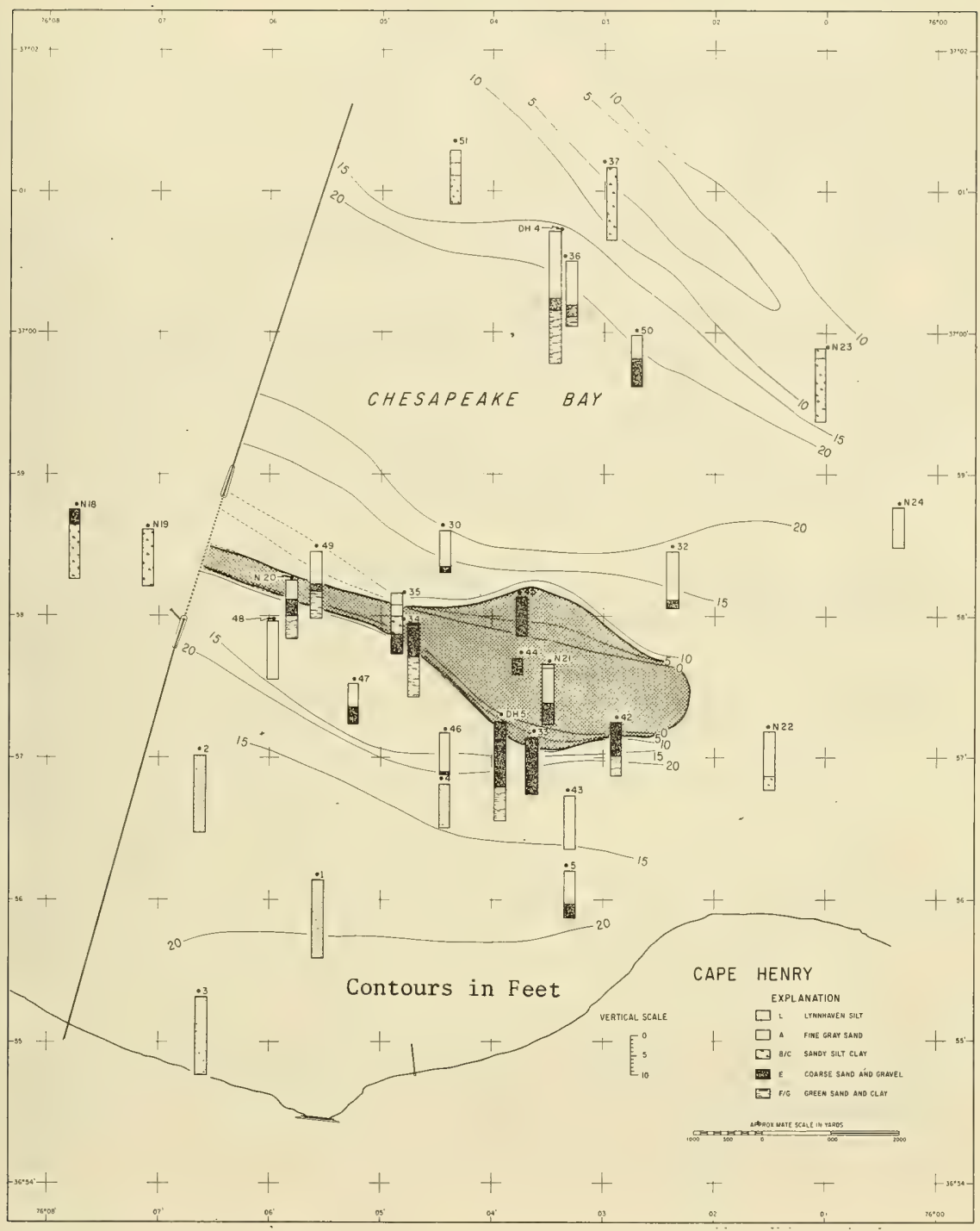

Figure 16. Detailed plan view of the Thimble Shoals outcrop of Type E sand. Crosshatched area outlines the area of outcrop or near outcrop where the most economically recoverable material lies. Contours are on the first subbottom reflector. 

The entrance to Chesapeake Bay study area lies between Cape Charles and Cape Henry encompassing shallow portions of lower Chesapeake Bay and the adjacent Atlantic Continental Shelf.

Wide expanses of sandy to silty bottom in less than 35 feet of water characterize the entrance. These shallow flats are cut by deeper channels reaching -40 to -90 feet MLW; locally, linear shoals and depressions create depths of -50 feet to less than -10 feet.

Borings in the Bay Entrance show that it is underlain by Miocene, Pleistocene and Holocene sediments. Seismic reflection records showing bedding in sediments to -300 feet MLW indicate that the deeper strata underlying the Entrance area are more or less mutually parallel and dip gently toward the east and southeast. Most of these strata are thought to be Miocene. Shallower subbottom strata in Chesapeake Bay Entrance are complexly bedded; internal bedding surfaces, channels and discontinuous sediment lenses are characteristic.

Large channe1s, now filled and buried, cut under the Entrance area in an easterly and southeasterly direction. These channels are believed to be Pleistocene Channels of major streams now tributaries to Chesapeake Bay.

The dominant sediment in the Bay Entrance is a fine to very fine gray sand which covers much of the northern two thirds of the area. Silt occupies Lynnhaven Bay and covers much of the channel floor. Coarse, gravelly sand is exposed locally in Thimble Shoals Channel and occurs in patches elsewhere.

Sand suitable for nourishment of ocean beaches within reasonable hauling distance of the Bay Entrance occurs only in the coarse sand and gravelly sand exposure in Thimble Shoals Channel. It is estimated that $19.4 \times 10^{6}$ cubic yards of this sand can be obtained either in exposure or under less than 5 feet of overburden.

It is estimated that $1.8 \times 10^{9}$ cubic yards of the fine gray sand has accumulated in the Bay Entrance. This sand is considered to be Holocene age and derived primarily from sources on the adjacent Atlantic Shelf or littoral rather than from Bayward sources. The coarse gravelly sand of Thimble Shoals Channel is believed to be a relict fluvial deposit of Pleistocene age or earlier. The silty sediments of the channels and in Lynnhaven bay are judged to be of Holocene age. 


\section{APPENDIX A}

\section{SELECTED GEOPHYSICAL PROFILES}

Appendix A contains line profile drawings of selected seismic reflection records from the Bay Entrance grid area.

"Fix" numbers and points of crossing lines are plotted along the upper margin of the profile.

The bottom and all subbottom reflectors are delineated and those reflectors mentioned in the text are identified by letter symbols.

A11 depths are in feet below mean sea level; and based on an assumed sound velocity of 4,800 feet per second in water and 5,440 feet per second in the subbottom.

Position of lines and fixes are plotted on Figures $2 \mathrm{a}$ and $2 \mathrm{~b}$. 


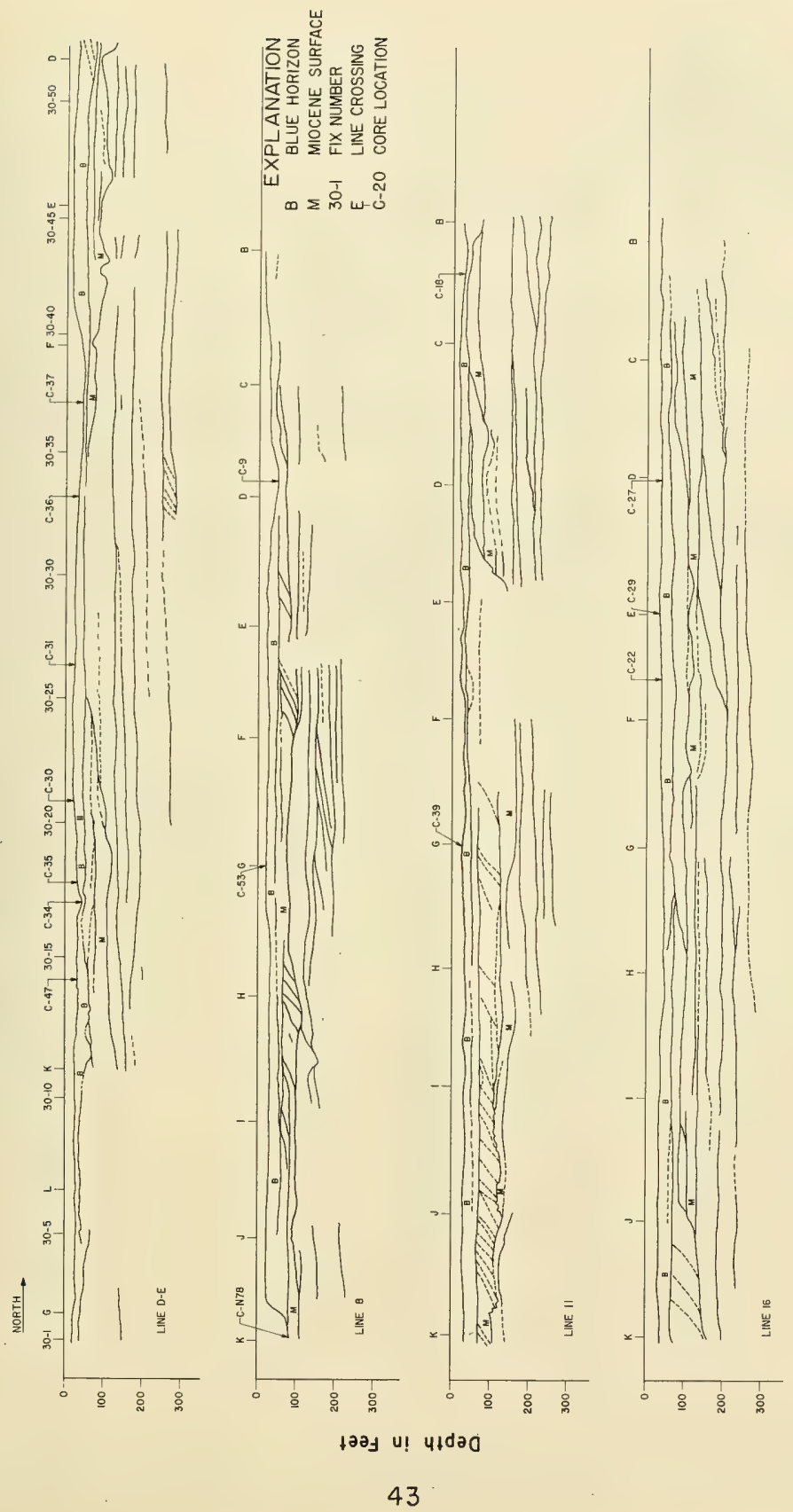




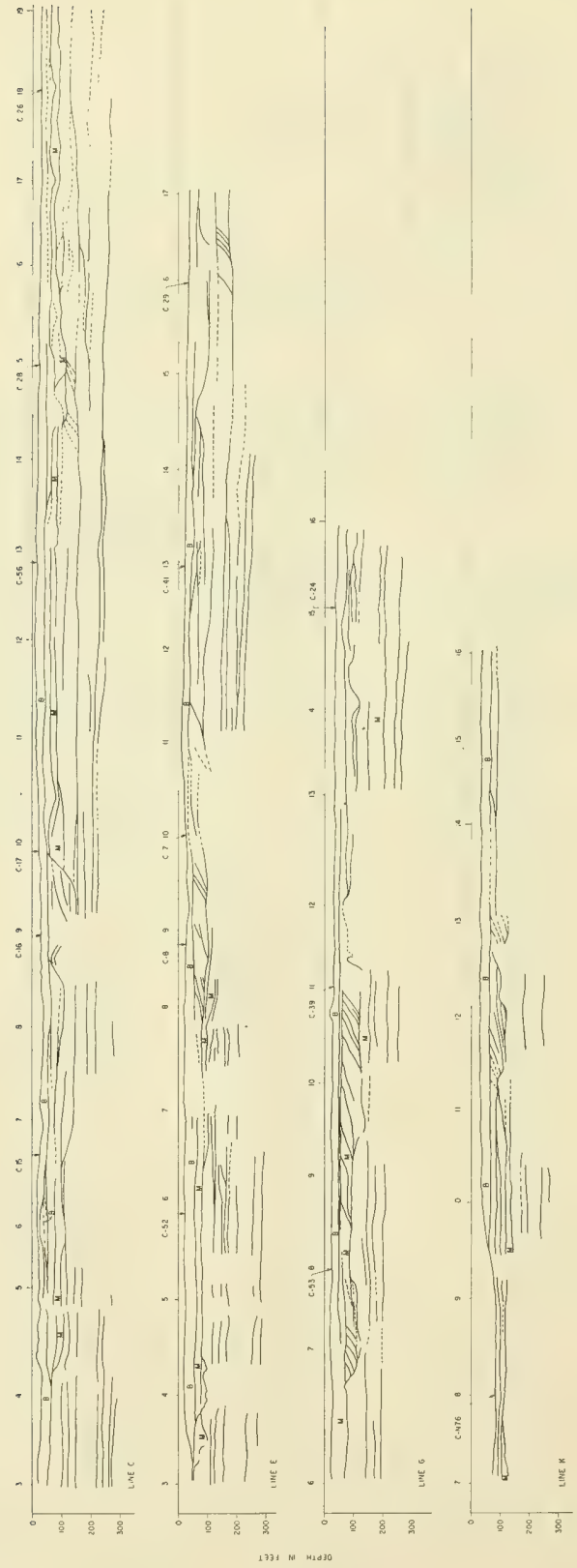


APPENDIX B

GRANULOMETRIC DATA

Appendix B contains the results of size analysis of selected samples from the study area.

Samples are identified by core number, CERC identity number, and sample interval within the core. These samples are plotted by core number on Figure 2 .

Size analysis data for all cores are filed with the National Oceanographic Data Center, of the National Oceanographic and Atmospheric Agency, U. S. Department of Commerce, Washington, D. C. and at the Coastal Engineering Research Center, Washington, D. C. 


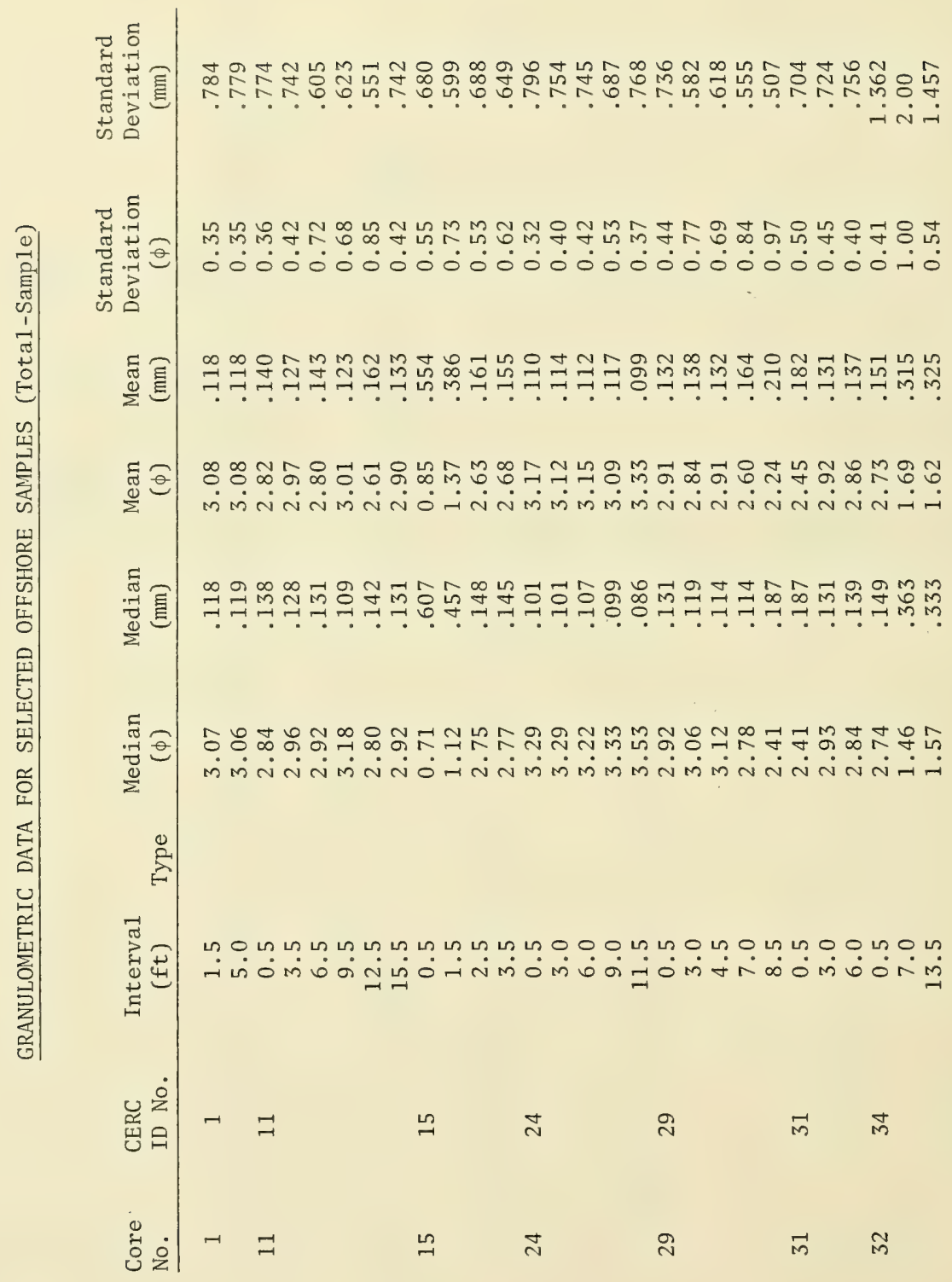




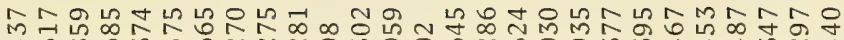

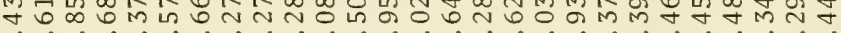

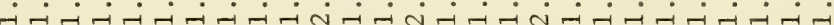
in

กำ

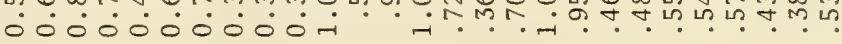

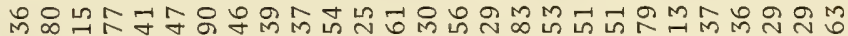

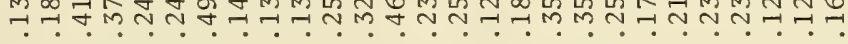

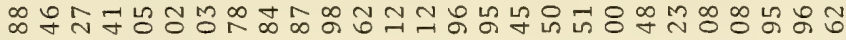

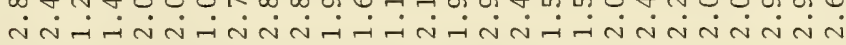

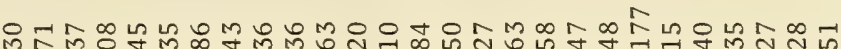

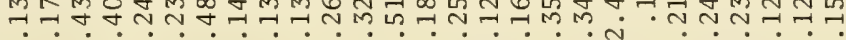

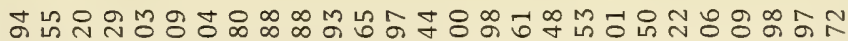

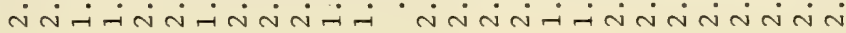

o. o n m

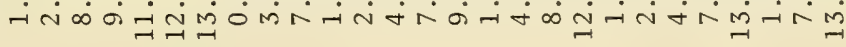

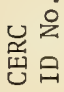

m

$\underset{\gamma}{\sim}$

กี

$\stackrel{6}{10}$

is

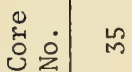

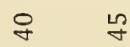

in

ธุ

in 
APPENDIX C

SEDIMENT DESCRIPTIONS

Appendix C contains visual description of sediments contained in cores from the study area.

Core number, CERC identification number, and sample depth in core are listed to the left. The cores are plotted on Figures $2 \mathrm{a}$ and $2 \mathrm{~b}$.

Visual descriptions are based on both megascopic and microscopic examination. The descriptive statement generally contains (in order) the following elements:

1. Color

2. Color code per Munse11 Soil Color Charts (1954 Edition)*

3. Dominant size or size range.

4. Major compositional element or elements with the dominant constituent listed first.

*Color code for Norfolk Dredging survey and from Christians and Meisburger (1967) are not available from the original logs.

* Munse11 Soil Color Charts, 1954 Edition, Munse11 Color Co., Inc., Baltimore, Maryland 


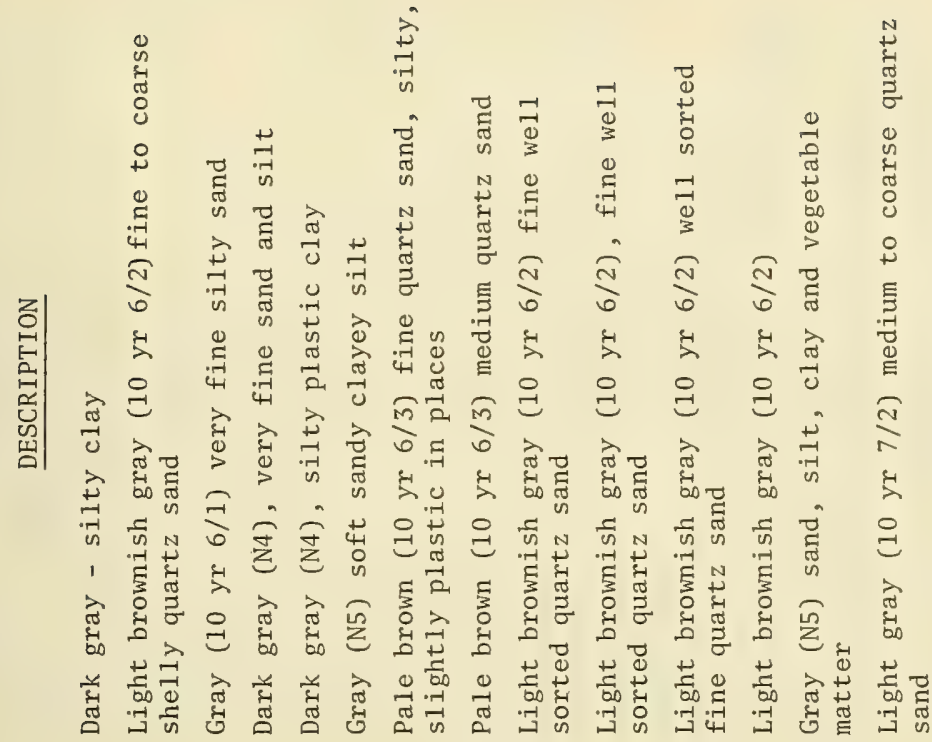

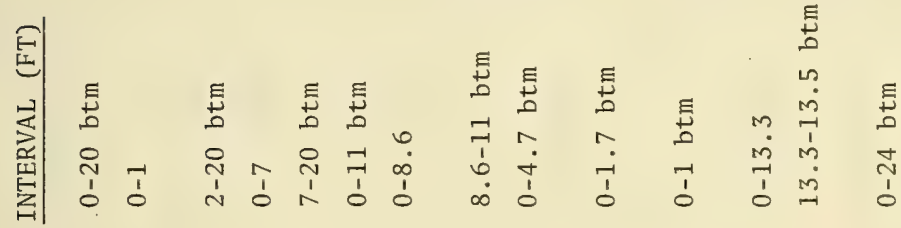

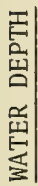

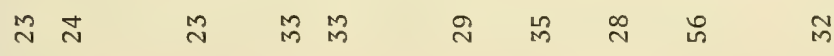

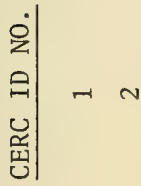

$m+$ in $0 \circ \infty \circ$

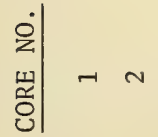

M $\quad$ Ln

$\infty \pi \cdot \infty$ or

오 


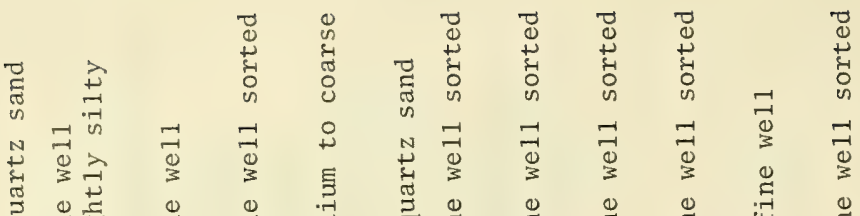

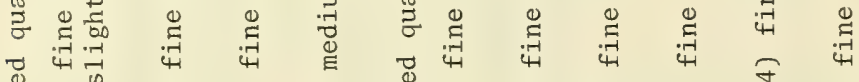

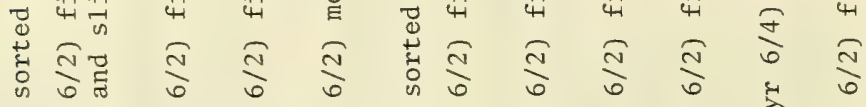

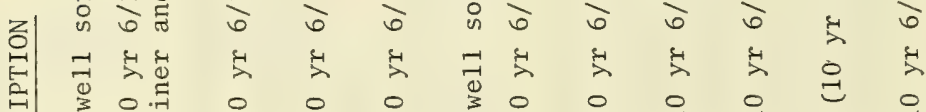

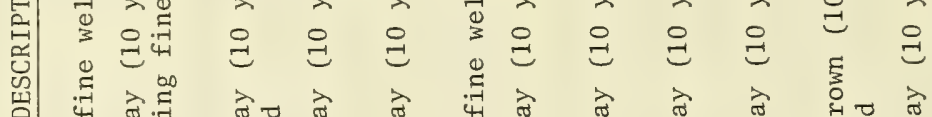

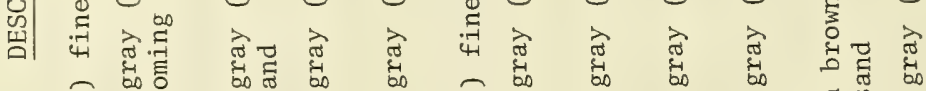
₹

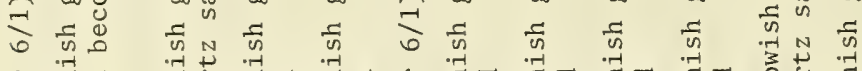

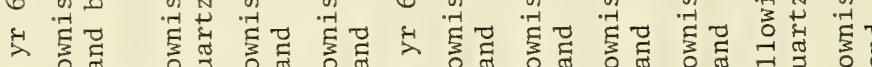

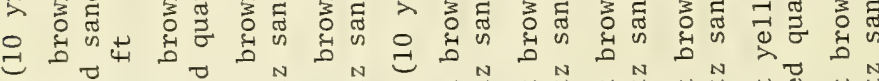

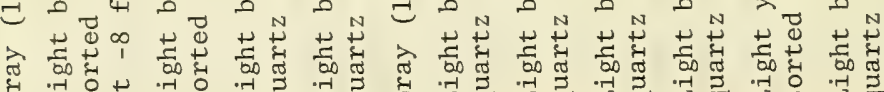

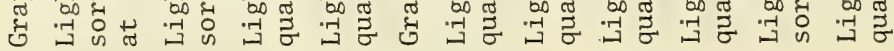

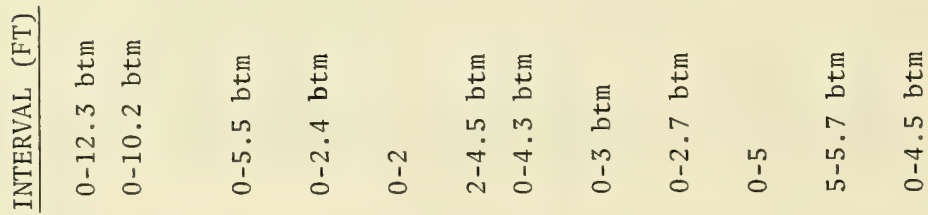

롬

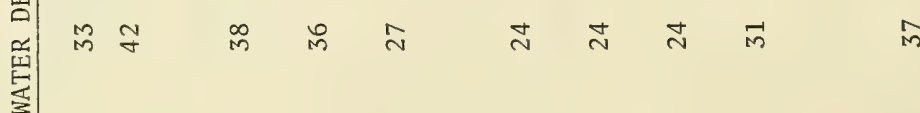

ஓं

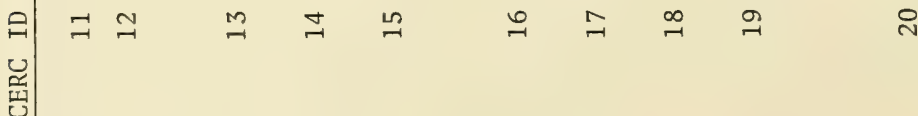

总

우 


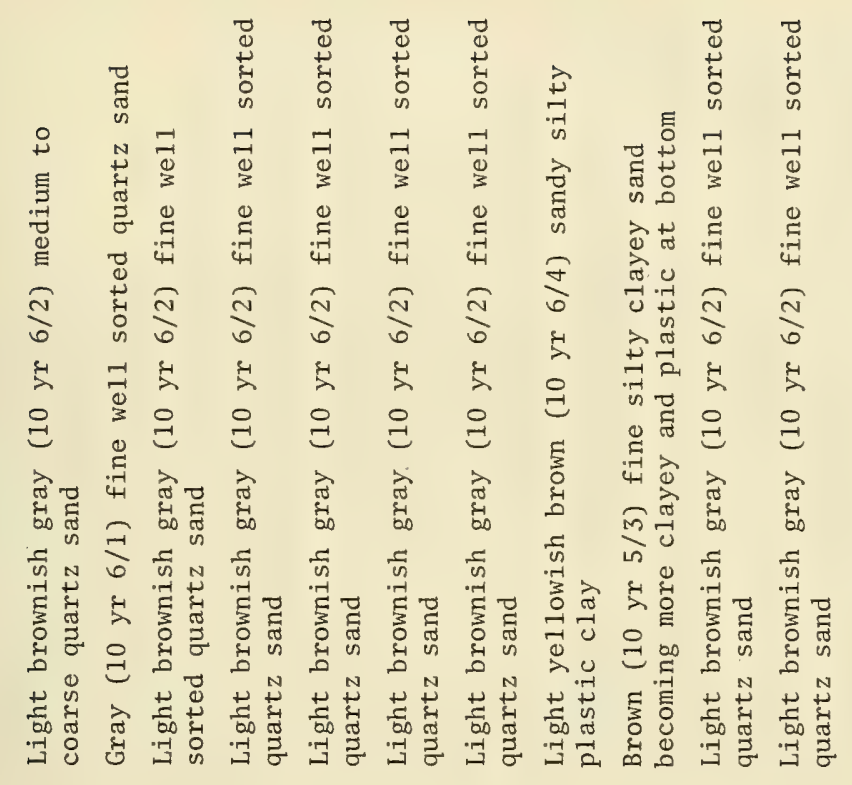

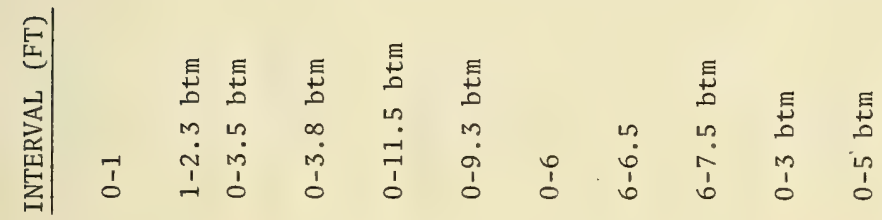

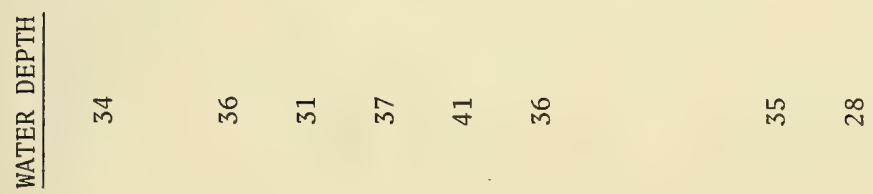

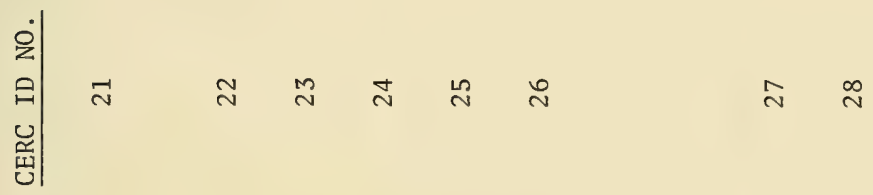

粼 


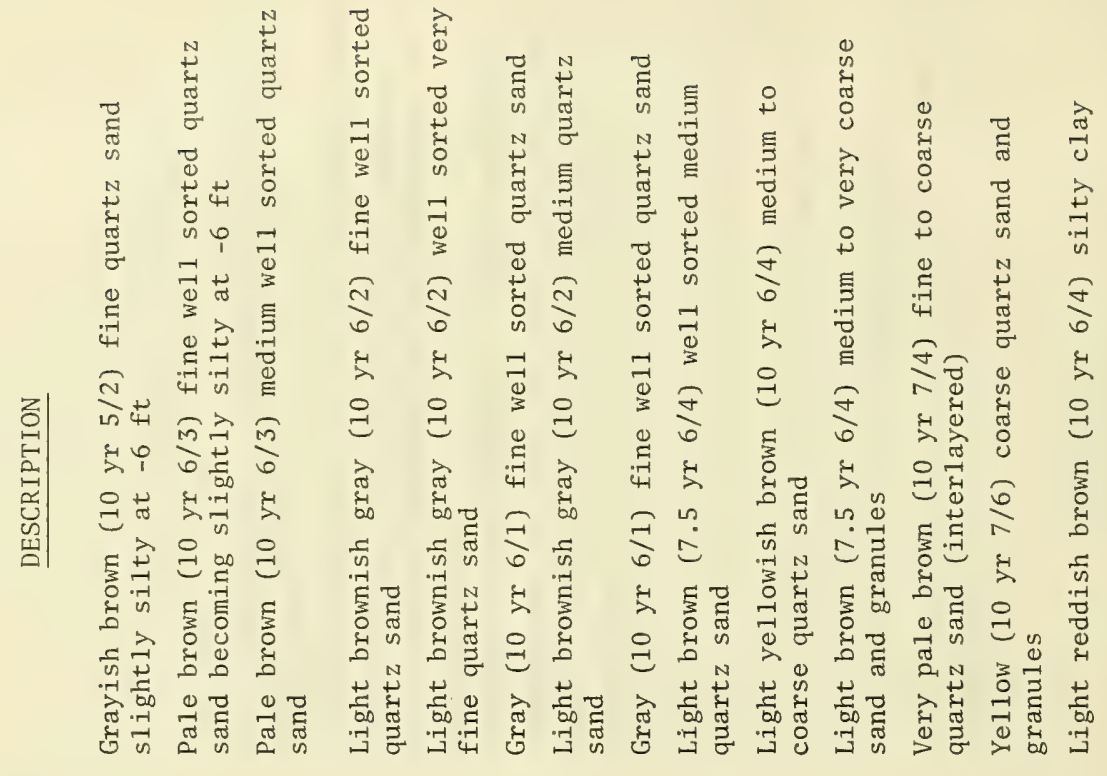

$$
\begin{aligned}
& \text { 島地 }
\end{aligned}
$$

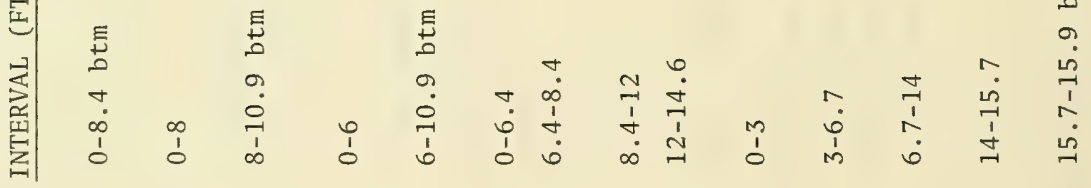

$$
\begin{aligned}
& \text { 章 }
\end{aligned}
$$

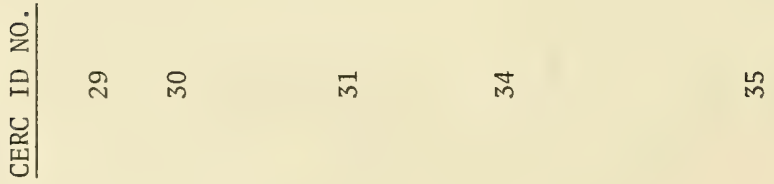

$$
\begin{aligned}
& \text { 离 }
\end{aligned}
$$


$\begin{array}{rlllll} & \\ 0\end{array}$

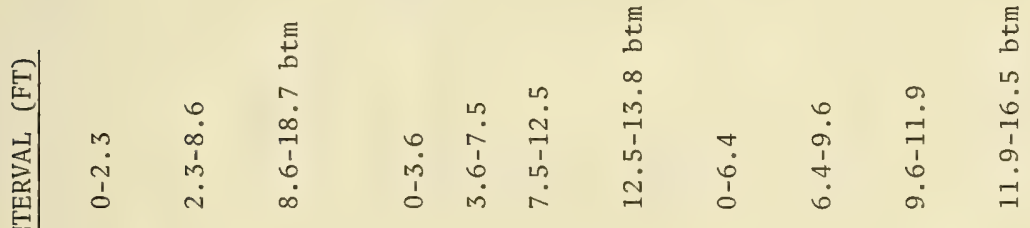

部

으 तิ

in

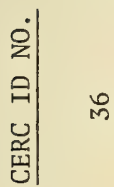

in

$\stackrel{\infty}{m}$

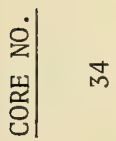

M

in 


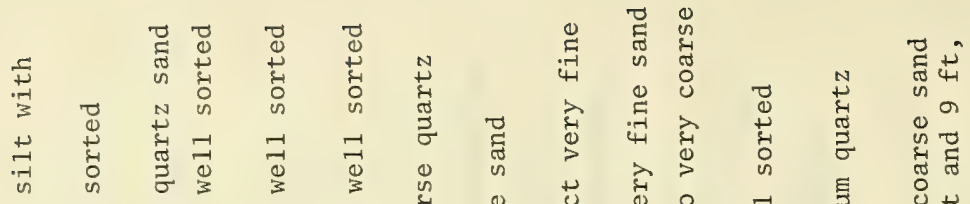

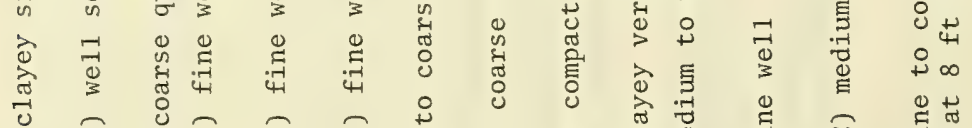

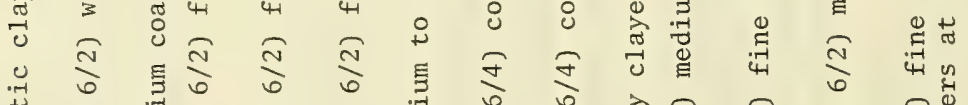

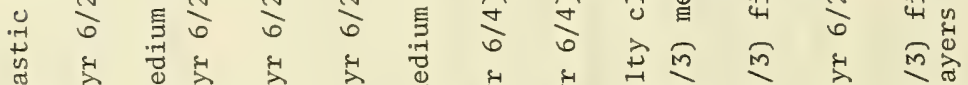

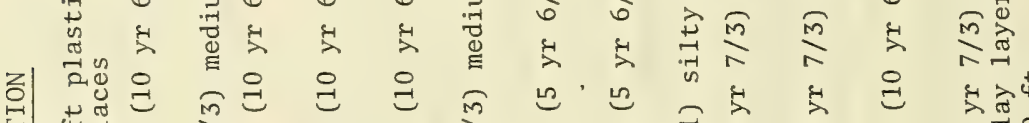

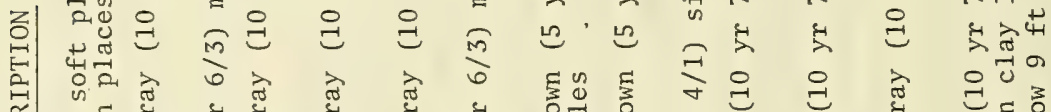

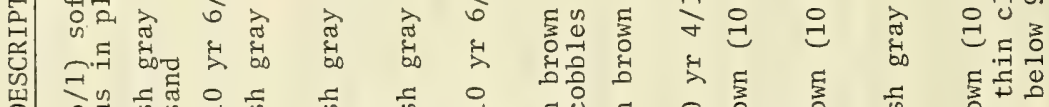

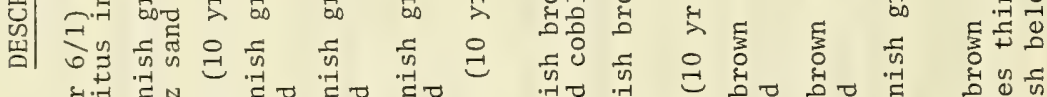

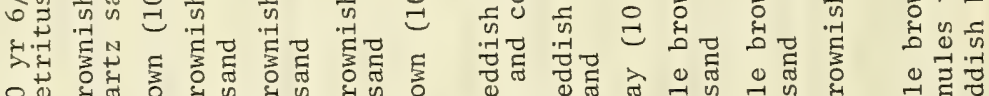

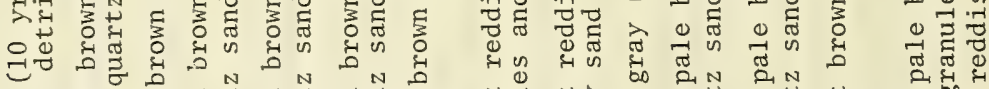

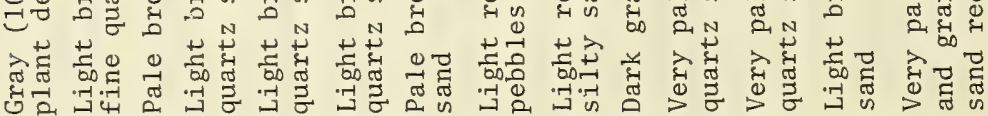

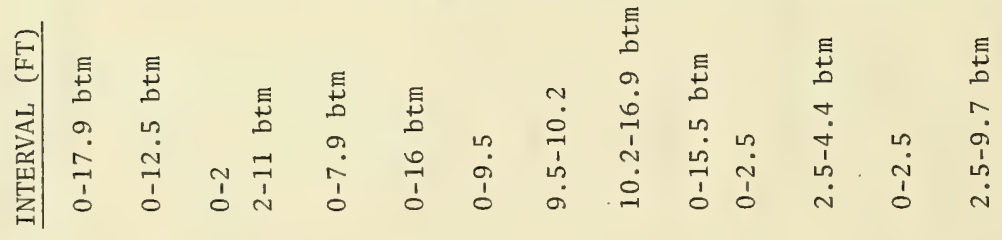

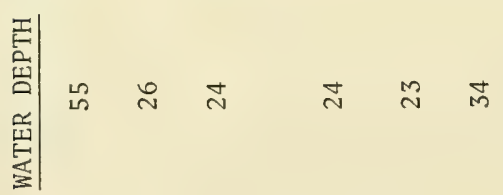

N $\stackrel{\infty}{\forall}$

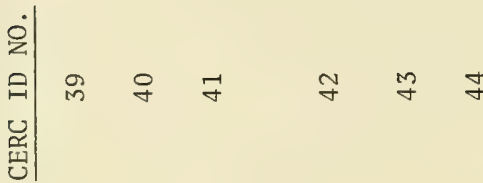

$\frac{d}{2} \underset{2}{2}$

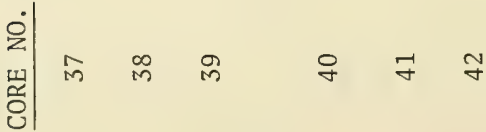

$\stackrel{d}{\&}$

L 


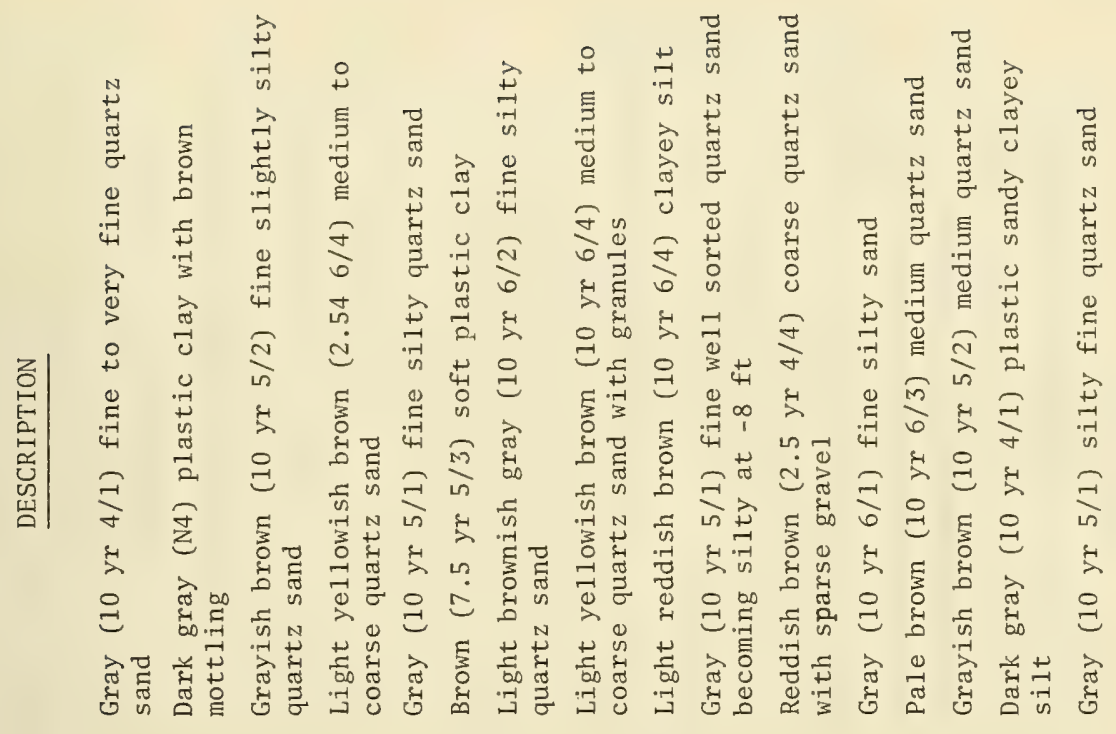

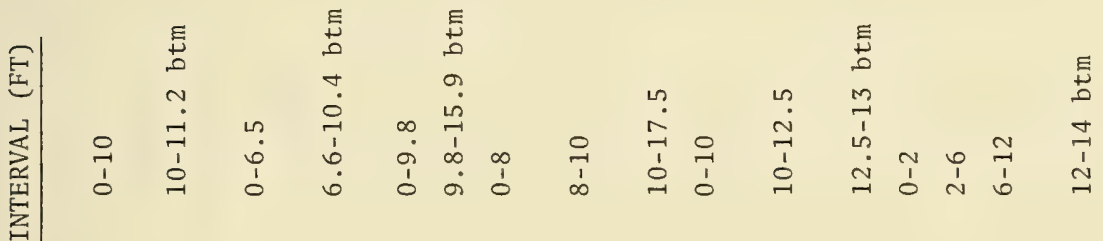

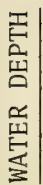

$\dot{8}$

으

$\stackrel{\infty}{+} \quad g$

ㅇ 오 드

iे

m

崫

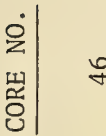

\&

$\stackrel{\infty}{+} \stackrel{g}{q}$

오

है 


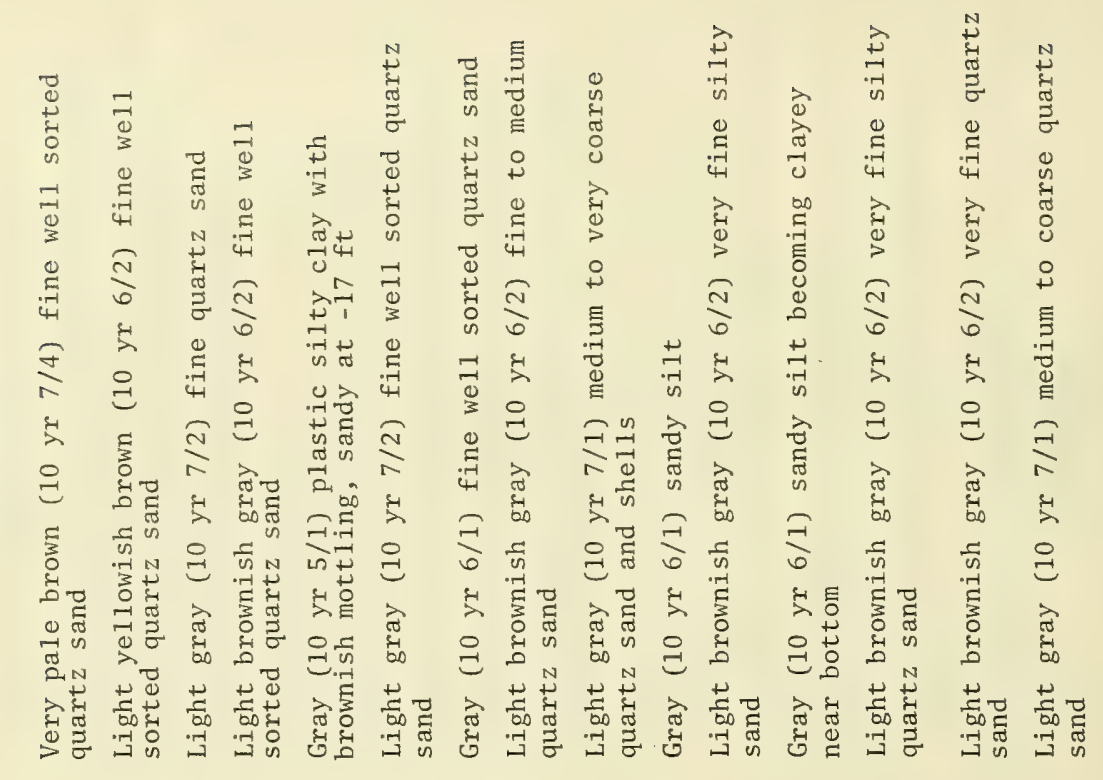

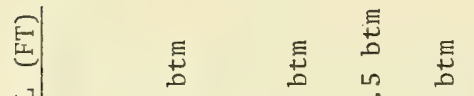

部

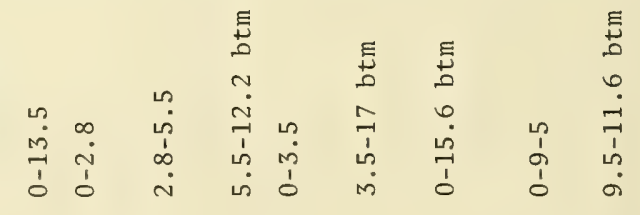

這

$\stackrel{M}{N}$

$\stackrel{N}{N}$

느

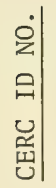

เั

in in

ஸ ก

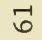

ชี

$\dot{0}$
$z$
밍
이

in in เ

เก กิ เก

กิ

인 


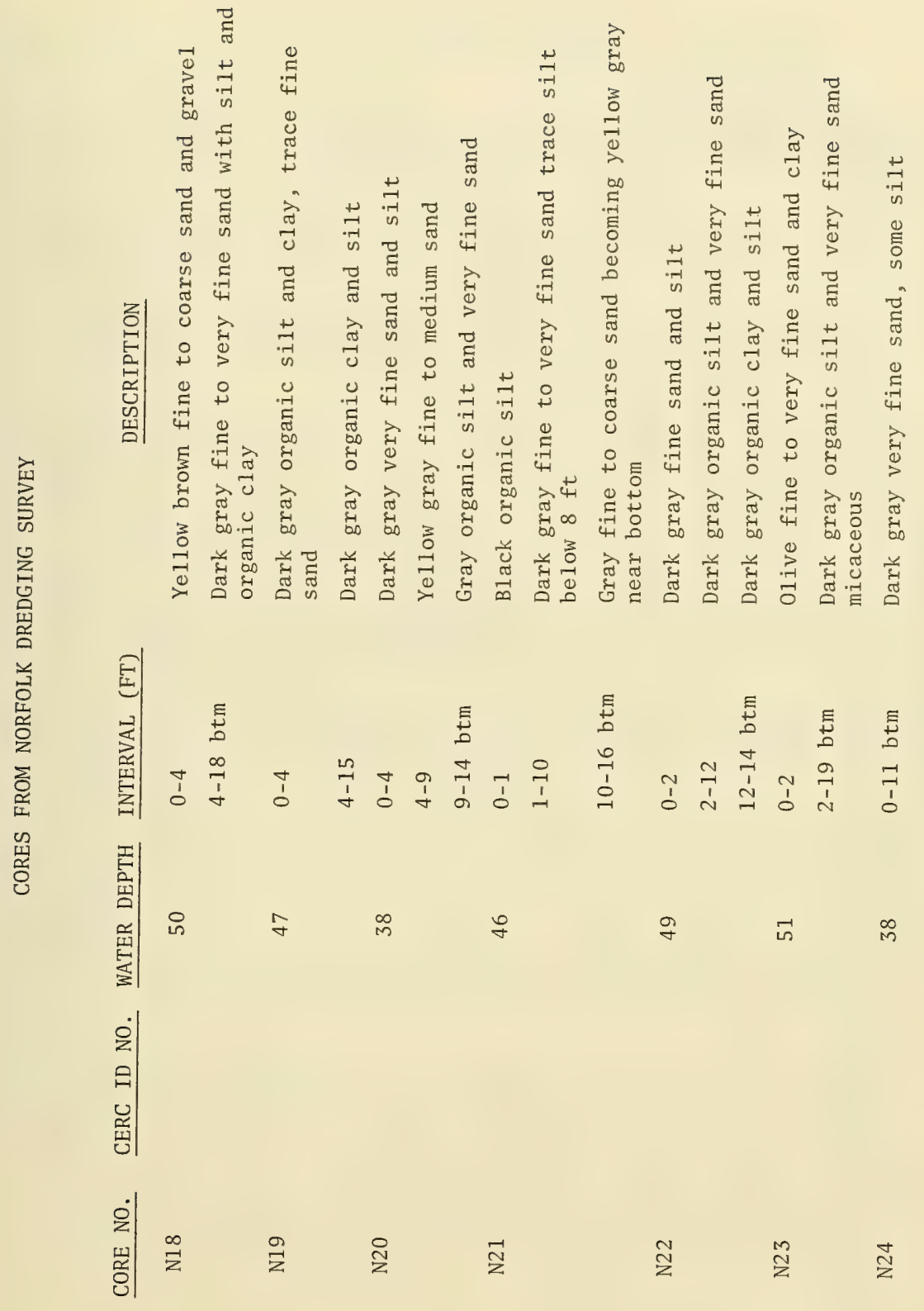




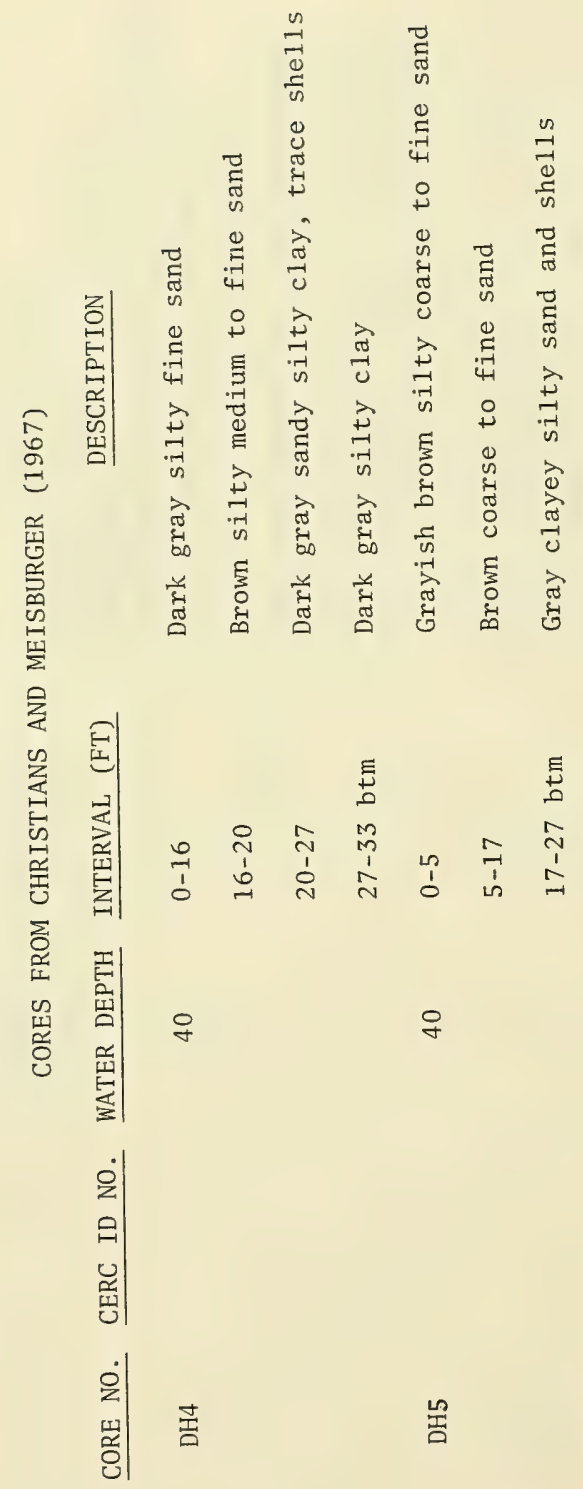




\section{LITERATURE CITED}

Beckmann, Walter C., Drake, Charles L. and Sutton, George H. (1961) SDR Survey for proposed Chesapeake Bay Crossing, Trans. ASCE, V126, Part IV, pp. 278-290.

Biggs, R. B., 1970, Sources and Distribution of Suspended Sediment in Northern Chesapeake Bay, Marine Geology, V9, N. 3, pp. 187-201.

Cederstrom, D. J., 1945, Geology and Ground Water Resources of the Coastal Plain in Southeastern Virginia, Virginia Geological Survey, Bulletin 63.

Chesapeake Bay Bridge and Tunnel Commission, 1960-1961, Engineering Logs of Borings, Moran, Proctor, Mueser and Rutledge, File No. 1970.

Christians, J. A. and Meisburger, E. P., 1967, Development of Multi-leg Mooring System, Phase A Explosive Embedment Anchor, U. S. Army Mobility Equipment Research and Development Center, Report 1909-A.

Coch, Nicholas, K., 1965, Post-Miocene Stratigraphy and Morphology, Inner Coastal Plain, Southeastern Virginia, Technical Report No. 6 Under NONR Contract 609(40) Task Order NR 388-064. (PhD dissertation Yale University, Unpb.).

Duane, David B. and Meisburger, Edward P., 1969, Geomorphology and Sediments of the Nearshore Continental Shelf, Miami to Palm Beach F1orida, CERC, Tech. Memo. No. 29.

Ewing, J. I., 1963, Elementary Theory of Seismic Refraction and Reflection Measurements, Chapter 1 in The Sea. V3, The Earth Beneath the Sea, Interscience Pub., New York, pp. 3-19.

Ewing, Maurice, Crary, A. B., Rutherford, H. M., and Miller, Benjamin, 1937, Geophysical Investigations in the Emerged and Submerged Atlantic Coastal Plain, Geol. Soc. America, Bull., V48, pp. 753-812.

Hack, J. T., 1957, Submerged River System of Chesapeake Bay, Geol. Soc. American Bu11.; V68, pp. 817-830.

Haight, F. J., 1942, Coastal Currents Along the Atlantic Coast of the United States, U. S. Coast and Geodetic Survey, Special Pub. 230.

Haight, F. J., Finnegan, H. E., Anderson, G. L., 1930, Tides and Currents in Chesapeake Bay, U. S. Coast and Geodetic Survey, Special Pub. No. 162. 
Harrison, Wyman B., 1963, Pleistocene Record in the Subsurface of the Norfolk Area, Virginia, in Guidebook for Field Trips. Norfolk Meeting - 1962, Virginia Academy of Science.

Harrison, W., Malloy, R. J., Rusnak, G. A., Terasmae, J., 1965, Possible Late Pleistocene Uplift, Chesapeake Bay Entrance, Journal of Geo1., V73, N. 2, pp. 201-229.

Harrison, W., Norcross, J. J., Pore, N. A., Stanley, E. M., 1967, Circulation of Shelf Waters Off Chesapeake Bight, ESSA Professional Paper No. 3.

Hersey, J. B., 1963, Continuous Reflection Profiling, V3, Chap. 4, The Sea, The Earth Beneath the Sea, Interscience Pub., New York, pp. 47-72.

Ludwick, John C., 1970, Sand Waves and Tidal Channels in the Entrance to Chesapeake Bay, Institute of Oceanography 01d Dominion University, Tech. Report No. 1.

McLean, James D., Jr., 1966, Miocene and Pleistocene Foraminifera and Ostracods of Southeastern Virginia, Virginia Department of Conservation and Economic Dev., Div. of Mineral Resources, Report of Investigations No. 9.

Miller, H. J., Tirey, G. B., Mecarini, G., 1967, Mechanics of Mineral Exploration, American Society of Mechanical Engineers, Underwater Technology, Conference, 1967.

Moore, D. G., and Palmer, H. P., 1968; Offshore Seismic Reflection Surveys, in Civil Engineering in the Oceans, ASCE, pp. 780-806.

Ne1son, Eric G., 1969, Foraminiferal Faunas and Depositional History from Cores at the Entrance to Chesapeake Bay, unpublished manuscript, Virginia Institute of Marine Science.

Nelson, Eric G., and Meisburger, E. P., 1972, Holocene Sedimentary Facies in Chesapeake Bay Entrance, [abs], GSA Southeast Section Annual Meeting.

Oaks, Robert Q, 1964, Post-Miocene Stratigraphy and Morphology, Outer Coastal Plain, Southeastern Virginia PhD dissertation, Yale Univ. also Tech. Report \#5, under Contract NONR $690(40)$ Task Order NR 388-064, Geog. Br. ONR.

Oaks, Robert Q. and Coch, Nicholas, K., 1963, Pleistocene Sea Levels, Southeastern Virginia, Science, V140, N 3570, pp. 979-983. 
Richards, H. G., 1967, Stratigraphy of Atlantic Coasta1 P1ain Between Long Island and Georgia - Review, American Assoc. Petroleum Geologists. Bul1. V51, N12, pp. 2400-2429.

Rogers, Wiley S. and Spencer, R. S., 1968, The Pleistocene Geology of Princess Anne County, Virginia, Southeastern Geology V9, Issue 2.

Ryan, J. Donald, 1953, The Sediments of Chesapeake Bay, Maryland Department of Geology, Mines and Water Resources, Bul1. 12, 120 pp. 18 plates.

Sinnott, Allen and Tibbitts, G. Chase, Jr., 1957, Subsurface Correlations Based on Selected Well Logs from the Eastern Shore Peninsula, Virginia, Virginia Div. of Mineral Resources. Mineral Resources Circular No. 6.

Sinnott, Allen and Tibbitts, G., 1954, Summary of Geology and Ground Water Resources of the Eastern Shore Peninsula, Virginia, Virginia Dept. of Conservation and Development, Div. of Geology and Mineral Resources, Circular No. 2.

Sinnott, Allen and Tibbitts, G. Chase, Jr., 1956, Records of Selected Wells on the Eastern Shore Peninsula, Virginia. Virginia Dept. of Concervation and Development, Div. of Geology and Mineral Resources, Circular No. 3.

U. S. Coast and Geodetic Survey, 1967, Tidal Current Tables, Atlantic Coast of N. America, U. S. Dept. of Commerce, ESSA, Washington, D. C.

U. S. Coast and Geodetic Survey, 1971, Tide Tables, East Coast of North and South America, U. S. Dept. of Commerce, ESSA, Washington, D. C. 



\section{DOCUMENT CONTROL DATA : R \& D}

(Securlty clessllication of tille, body of abstract and indexing ennotation must be entered when the overall repost ls ctasalled) 1. ORIGINATING ACTIVITY (Corporate author)

Coastal Engineering Research Center (CERC) Corps of Engineers, Department of the Army Washington, D.C. 20016 3. REPORT TITLE

\section{GEOMORPHOLOGY AND SEDIMENTS OF THE CHESAPEAKE BAY ENTRANCE}

4. DESCRIPTIVE NOTES (Type of report and Inclusive datea)

8. AU THOR(S) (FIrst name, middie Inltial, last name)

Edward P. Meisburger

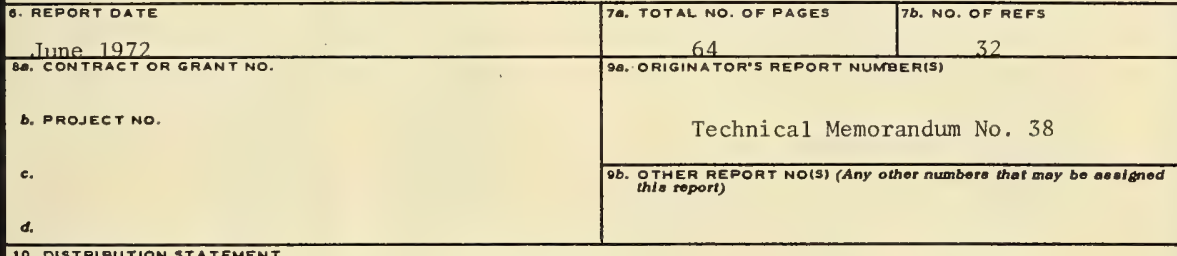

Approved for public release; distribution unlimited.

Coastal Engineering Research Center 5201 Little Falls Rd., N. W. Washington, D. C. 20016

The entrance of the Chesapeake Bay and the Atlantic Ocean in the vicinity of Cape Charles and Cape Henry were surveyed to study the bottom morphology and sediments, and subbottom structure, in an effort to locate suitable sand deposits in volumes great enough to economically restore and periodically nourish the shore. Seismic reflection profiles and sediment cores were the basis for the study. Field and laboratory techniques used for the profiles and sediment obtained from the sea floor in lower bay and ocean are presented. Most of the study area is less than 35 feet deep; distribution of shallow bay and inshore terraces and deeper water are shown in the figures. The study included analyses of borings taken along the route of the Chesapeake Bay Bridge Tunnel by the Bridge Commission in 1960 and 1961. Cores obtained for a dredging study by the Norfolk District, Corps of Engineers, 1970, were made available and were used in the study. 


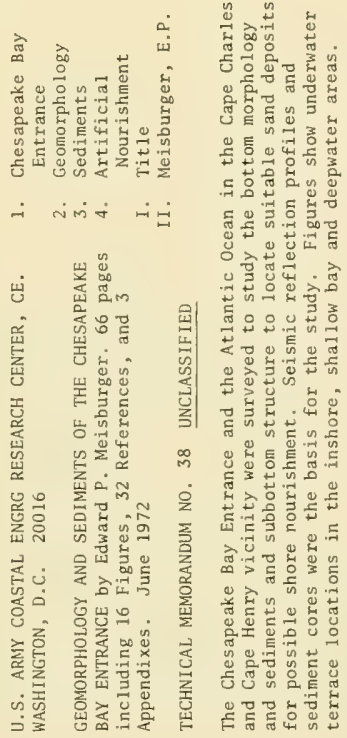

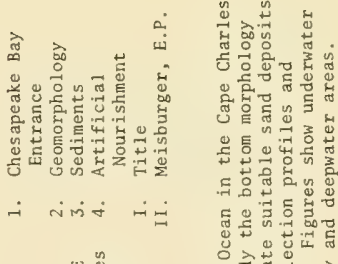

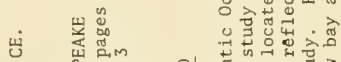

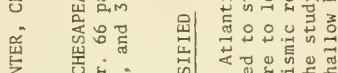

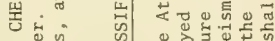

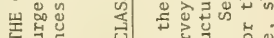

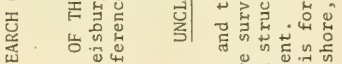

㟧

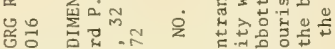

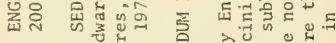

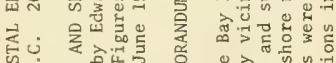

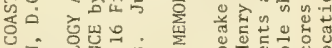

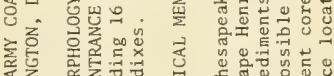

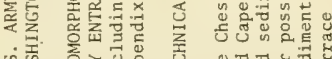

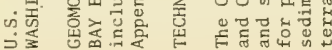

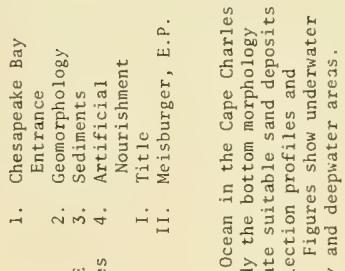

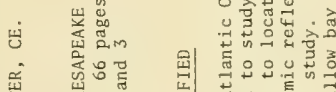

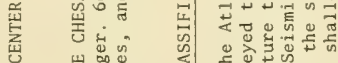

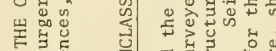

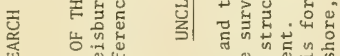

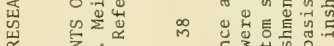

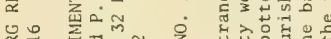

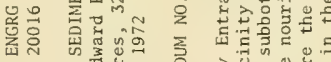

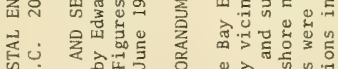

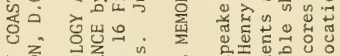

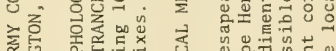

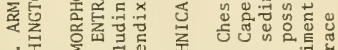

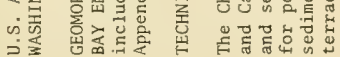

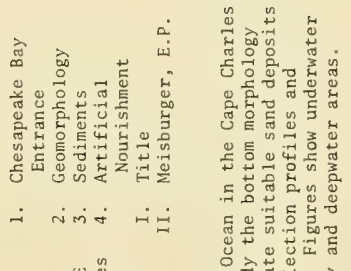

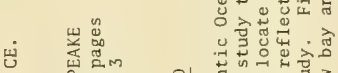

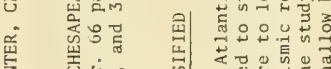

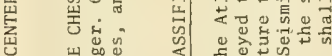

岸骂哭

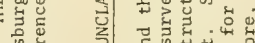

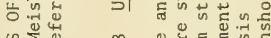

फ

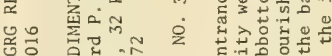

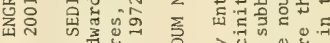

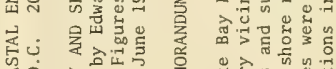

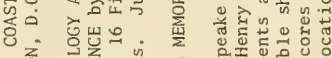

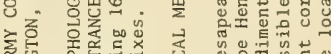

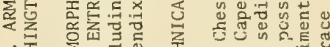

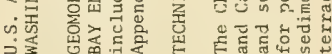





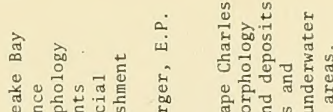

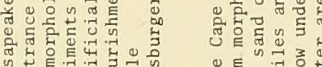

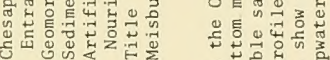

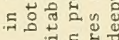

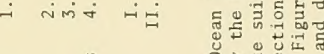

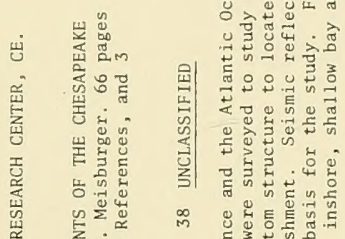

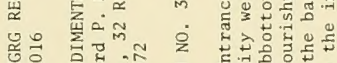

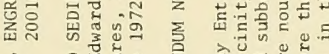

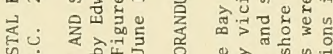

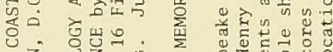

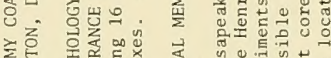

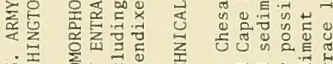

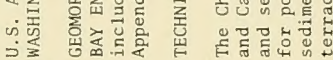

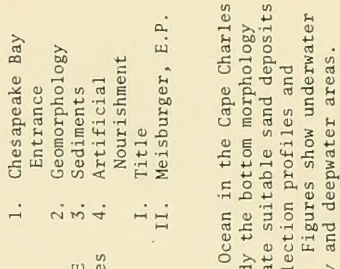

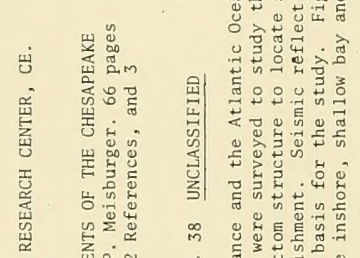

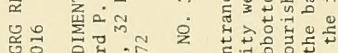

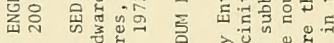

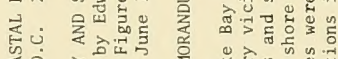

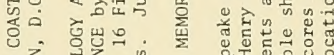

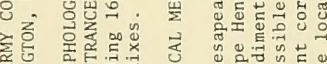

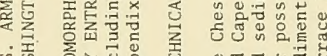

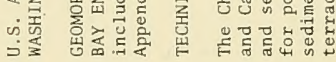

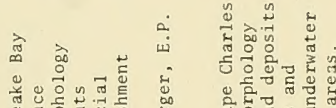

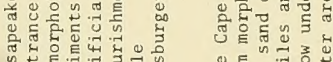

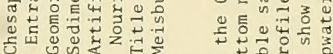

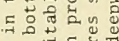

- 整

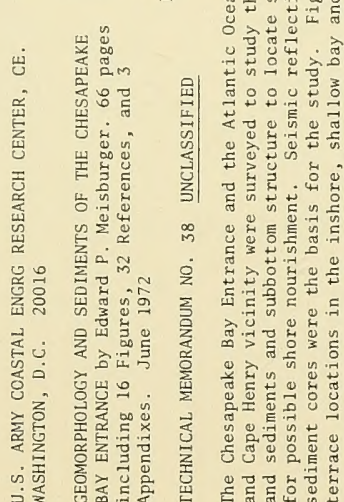

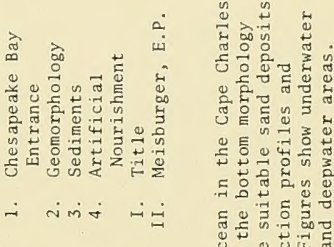

i⿺辶寸

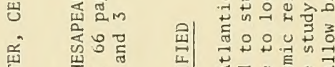

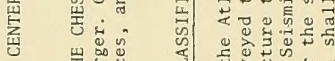

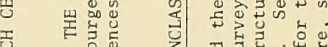

플.

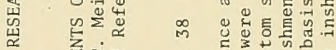

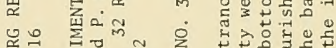

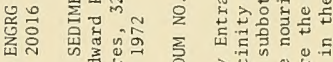

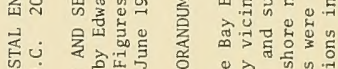

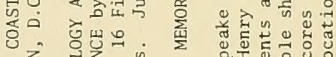

خ登

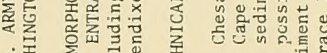

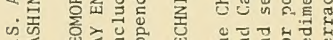




